\title{
Checks and Balances in an Era of Presidential Lawmaking
}

\author{
Abner S. Greene†
}

Perhaps there was no argument urged with more success, or more plausibly grounded against the Constitution, under which we are now deliberating, than that founded on the mingling of the Executive and Legislative branches of the Government in one body.

-James Madison ${ }^{1}$

Madison's admonition against mingling executive and legislative powers was central to the federal government as devised in $1787 .^{2}$ Today, though, this precept is often ignored. We accept, perhaps uneasily, the delegation of substantial lawmaking power to the President, who executes the laws he makes. Of course we don't call the President's power "lawmaking." We have euphemisms-we call this power "regulatory," or "interpretive," or "gap-filling." But as we know from cases such as Cheuron, U.S.A., Inc. v Natural Resources Defense Council, Inc., ${ }^{3}$ the delegation from Congress is often vague or silent on a key issue, and the resulting rule-from either rulemaking or adjudication-is a policy choice in much the same way that statutes are policy choices. ${ }^{4}$

† Visiting Associate Professor of Law, Benjamin N. Cardozo School of Law, Yeshiva University. Many thanks for helpful suggestions from David Currie, Richard Epstein, Steve Gilles, Dan Kahan, Jessica Korn, Larry Lessig, Michael McConnell, John McGinnis, Geoff Miller, John Nagle, Steve Schulhofer, Dan Shaviro, Paul Shupack, David Strauss, Cass Sunstein, and participants in the University of Chicago Law School Work-in-Progress Luncheon. Also thanks to Beth Evans for valuable research assistance.

1 James Madison, House debate in First Congress, 1789, on the Foreign Affairs Department, reprinted in A. Stephen Boyan, Jr., ed, I Constitutional Aspects of Watergate 485 (Oceana, 1976).

2 Madison was referring to antifederalists who thought the Senate check on presidential appointments improperly gave the Senate executive power. While disagreeing with the antifederalists' conclusion in that instance, Madison nonetheless agreed that such "mingling" was a danger to be monitored carefully. In the debate just quoted, for example, he was arguing against a Senate role in the removal of executive officers.

${ }^{3} 467$ US 837, 843-44 (1984). See also Martin v Occupational Safety and Health Review Commission, 499 US 144, 151-53 (1991), referring to "interpretive lawmaking" done by agencies.

- See Chevron, 467 US at 865-66; Abner S. Greene, Adjudicative Retroactivity in Administrative Law, 1991 S Ct Rev 261, 274-82. 
Presidential lawmaking presents an unusual problem for constitutional theory. After all, the Constitution's text gives lawmaking power to Congress, reserving to the President only a qualified veto. So on a straightforward textualist view, presidential lawmaking would be unconstitutional. But we live with an enormous amount of such lawmaking, and few appear ready to condemn the system as invalid. If, therefore, we have accepted presidential lawmaking as constitutional, must we accept without reservation this concentration of executive and legislative power, or should we deem appropriate other structural responses that seek to reduce the agglomeration of presidential power?

This Article offers one approach to this problem-an approach grounded in a brand of originalism that seeks to adapt the framers' checks and balances principles to an era of presidential lawmaking they could hardly have foreseen. I suggest that if we accept sweeping delegations of lawmaking power to the President, then to capture accurately the framers' principles-principles that deserve our continuing adherence-we must also accept some (though not all) congressional efforts at regulating presidential lawmaking. ${ }^{5}$ Just as the framers saw their structural choices as parts of a package separating legislative from executive power to protect liberty and avoid governmental tyranny, so should we view checks and balances doctrine as a package, its specific elements subject to revision to ensure fidelity to the constitutional premise of divided governmental powers. This is not a "functionalist" or "realist" position; my arguments are not grounded in purely contemporary normative claims about democratic government. Rather, I try to show that by paying close attention to the principles that led the framers to make specific structural choices, we can better understand the sometimes confusing array of twentieth century cases addressing "framework" legislation, ${ }^{6}$ that is, legislation that structures the relationship between Congress and the President. Furthermore, I argue that attention to such principles requires reexamination, in certain narrowly defined circumstances, of the constitutionality of legislative vetoes, which were invalidated in one sweeping blow in INS $v$ Chadha. ${ }^{7}$

- The discussion is limited to domestic powers.

- See Gerhard Casper, Constitutional Constraints on the Conduct of Foreign and Defense Policy: A Nonjudicial Model, 43 U Chi L Rev 463, 482 (1976); Kenneth W. Dam, The American Fiscal Constitution, 44 U Chi L Rev 271, 272 (1977).

7462 US 919 (1983). 
After laying out my working assumptions in Section I, I turn, in Section II, to historical information from the framing period. Here, I show that beyond any particular arrangement of power between the President and Congress, the framers were overwhelmingly concerned with either political branch aggrandizing its own power without sufficient checks. To the extent that there is any "original understanding" of the division of power between the President and Congress, it is that both are to be feared, neither is to be trusted, and if either one grows too strong we might be in trouble. The framers' support for a strong, unitary executive cannot be understood apart from the limited powers they gave to the executive, nor apart from their need to create an executive strong enough to counteract overreaching legislatures.

In the post-New Deal world, however, the framers' factual assumptions have been displaced. Now, it is the President whose power has expanded and who therefore needs to be checked.8 $\mathrm{My}$ central claim in Section III is that we must examine contemporary checks and balances problems from the premise of an underenforced nondelegation doctrine, that is, from the premise that Congress gives away great swaths of lawmaking power, and that the Supreme Court does not do anything about it. Although often criticized as inconsistent, as wavering between formalism and functionalism, ${ }^{9}$ much of the Court's post-New Deal checks and bal-

B See William N. Eskridge, Jr., and John Ferejohn, The Article I, Section 7 Game, 80 Georgetown L J 523, 533 (1992).

- See, for example, Rebecca L. Brown, Separated Powers and Ordered Liberty, 139 U $\mathrm{Pa}$ L Rev 1513, 1517-31 (1991); Harold H. Bruff, On the Constitutional Status of the Administrative Agencies, 36 Am U L Rev 491, 495-506 (1987); Steven G. Calabresi and Kevin H. Rhodes, The Structural Constitution: Unitary Executive, Plural Judiciary, 105 Harv L Rev 1153, 1167 n 62 (1992); Stephen L. Carter, From Sick Chicken to Synar: The Evolution and Subsequent De-Evolution of the Separation of Powers, 1987 BYU L Rev 719, 719-22 (describing fluctuation as between "evolutionary" (functional) and "de-evolutionary" (formal)); E. Donald Elliott, INS v. Chadha: The Administrative Constitution, The Constitution, and the Legislative Veto, $1983 \mathrm{~S} \mathrm{Ct}$ Rev 125, 126; Daniel J. Gifford, The Separation of Powers Doctrine and the Regulatory Agencies After Bowsher v. Synar, 55 Geo Wash L Rev 441, 447-48 (1987); Harold J. Krent, Separating the Strands in Separation of Powers Controversies, 74 Va L Rev 1253, 1254-55 (1988); Geoffrey P. Miller, Independent Agencies, 1986 S Ct Rev 41, 52-54 (referring to the Court's "pragmatic" and "neoclassical" approaches to separation of powers cases); Suzanna Sherry, Separation of Powers: Asking a Different Question, 30 Wm \& Mary L Rev 287, 289 (1989); Peter L. Strauss, Was There a Baby in the Bathwater? A Comment on the Supreme Court's Legislative Veto Decision, 1983 Duke L J 789, 804; Peter L. Strauss, Formal and Functional Approaches to Separation-of-Powers Questions-A Foolish Inconsistency?, 72 Cornell L Rev 488, 489 (1987); Paul R. Verkuil, Separation of Powers, The Rule of Law and the Idea of Independence, $30 \mathrm{Wm}$ \& Mary L Rev 301, 311-12 (1989). See also Harold H. Bruff, Presidential Power and Administrative Rulemaking, 88 Yale L J 451, 453, 479, 487-88 (1979) (advocating a flexible, functional approach, and criticizing the Court when it takes a rigid approach); E. Donald Elliott, Why 
ances jurisprudence can be justified as an attempt to ensure fidelity to the original understanding of checks and balances in a post-nondelegation doctrine world. The principle that synthesizes the case law is this: Congress may give away legislative power and insulate such delegated power from total presidential control, but Congress may neither draw executive power to itself nor seek to legislate outside the Article I, Section 7 framework. Insulation from presidential control, often accomplished through the establishment of independent agencies, restores a balance of powers ${ }^{10}$ by preventing the agglomeration of executive and legislative power in the President, without creating an unjustifiable "accountability gap" for undisciplined agencies. Other methods of congressional control risk replacing presidential with congressional tyranny.

Although the combination of validating independent agencies and invalidating various methods of congressional aggrandizement has gone a long way toward ameliorating the problem of concentrated legislative and executive power, the presidential veto looms as a structural threat. This might sound odd-we know that the framers intended the presidential veto to check an overreaching Congress. But in the post-nondelegation doctrine world, the presidential veto has served not only to prevent legislation the President deems unconstitutional or unwise, but also to entrench the President's own acts of lawmaking. To be faithful to the core commitment of dividing legislative from executive power, we must limit the "entrenching" presidential veto. In Section IV, I offer one restructuring suggestion, namely, that we recognize the constitutionality of concurrent resolutions adopted to block executive branch regulation that is indistinguishable from lawmaking.

In elaborating this theory of congressional power in a post-nondelegation doctrine world, I offer a third alternative to what has been primarily a bipolar debate. This debate, often focused on independent agencies, has divided those who support the President's ultimate power to remove all officers exercising execu-

Our Separation of Powers Jurisprudence Is So Abysmal, 57 Geo Wash L Rev 506, 508 (1989) (criticizing "literalism" in our separation of powers jurisprudence).

${ }^{10}$ Anticipating an argument of this sort, Geoffrey Miller states: "[T]he quid pro quo argument-that new mechanisms must be devised to check the radical increase in presidential power accompanying the rise of the administrative state-overlooks the fact that administrative government reflects an increase in the powers of all branches of the federal government, in particular the dramatically enhanced power of Congress under expansive interpretations of the Commerce Clause." Miller, $1986 \mathrm{~S} \mathrm{Ct}$ Rev at 56. I fail to see how this response addresses the problem of executive and legislative power concentrated in the hands of the President. 
tive power (the chain of command theorists) from those who back congressional power to regulate removals (the congressional regulation theorists). The debate usually turns on how one characterizes the Executive Power Vesting Clause, ${ }^{11}$ the Take Care Clause, ${ }^{12}$ and the second half of the Necessary and Proper Clause. ${ }^{13}$ The chain of command theory, supported by Steven Calabresi and Kevin Rhodes, David Currie, Daniel Gifford, Geoffrey Miller, Nathaniel Nathanson, Richard Pierce, Peter Strauss, and Paul Verkuil, ${ }^{14}$ goes something like this: Laws must necessarily be executed through a number of officials and not through the President himself, for the President cannot physically execute all the laws. But those executing the laws act as the President's agents, and thus must be controlled by the President to conform to his wishes. The congressional regulation theory, backed by Edward Corwin, Morton Rosenberg, and William Van Alstyne, ${ }^{16}$ goes something like this:

11 "The executive Power shall be vested in a President of the United States of America." US Const, Art II, § 1, cl 1.

12 "[The President] shall take Care that the Laws be faithfully executed." US Const, Art II, \& 3 .

1s "The Congress shall have Power . . . To make all Laws which shall be necessary and proper for carrying into Execution ... a all other Powers vested by this Constitution in the Government of the United States, or in any Department or Officer thereof." US Const, Art I, § 8, cl 18. See also Edward S. Corwin, Tenure of Office and the Removal Power Under the Constitution, 27 Colum L Rev 353, 359 (1927).

14 See Calabresi \& Rhodes, 105 Harv L Rev at 1165-66, 1176, 1184 n 158, 1215 (cited in note 9); David P. Currie, The Distribution of Powers After Bowsher, $1986 \mathrm{~S} \mathrm{Ct}$ Rev 19, 3435; Gifford, 55 Geo Wash L Rev at 465, $472-73$ (cited in note 9); Miller, 1986 S Ct Rev at 44 (cited in note 9); Nathaniel L. Nathanson, Separation of Powers and Administrative Law: Delegation, The Legislative Veto, and the "Independent" Agencies, $75 \mathrm{Nw}$ U L Rev 1064, 1104-09 (1981); Richard J. Pierce, Jr., The Role of Constitutional and Political Theory in Administrative Law, 64 Tex L Rev 469, 471-72, $507-13$ (1985); Peter L. Strauss, The Place of Agencies in Government: Separation of Powers and the Fourth Branch, 84 Colum L Rev 573, 599, 602, 615-16, 640-41, 648-49, 663 (1984); Paul R. Verkuil, The Status of Independent Agencies After Bowsher v. Synar, 1986 Duke L J 779, 799; Paul R. Verkuil, The Purposes and Limits of Independent Agencies, 1988 Duke L J 257, 265. See also Lee S. Liberman, Morrison y. Olson: A Formalistic Perspective on Why the Court Was Wrong, 38 Am U L Rev 313, 353, 357 (1989) (arguing that it is constitutional to restrict presidential removal power so long as statute is read to give President power to direct agent to act as President wishes); Thomas O. McGarity, Presidential Control of Regulatory Agency Decisionmaking, 36 Am U L Rev 443, 465 (1987) (arguing the converse of Liberman's position: "Congress may delegate decisionmaking power to inferior officers of the United States who are not agents of the President, but may be subject to presidential removal.").

15 See Corwin, 27 Colum L Rev at 382-86, 392-94 (Corwin would have required, though, that cabinet heads be removable by President at will); Morton Rosenberg, Congress's Prerogative Over Agencies and Agency Decisionmakers: The Rise and Demise of the Reagan Administration's Theory of the Unitary Executive, 57 Geo Wash L Rev 627, 634, 636, 650 (1989); William W. Van Alstyne, The Role of Congress in Determining Incidental Powers of the President and of the Federal Courts: A Comment on the Historical Effect of the Sweeping Clause, 40 L \& Contemp Probs 102, 107, 114-16, 118-19, 133 n 100 (Spring 1976) 
With regard to congressionally delegated power, the President is the agent of Congress, required to conform to its commands. If Congress thinks it proper for certain officials to be removable for good cause only, then that intent is an aspect of the law that the President must execute. It might be problematic for Congress entirely to insulate from removal an official performing executive functions, for then the President could not even ensure that the official was acting within her congressionally granted jurisdiction. But apart from this boundary-policing job, which might be inherent in the Take Care Clause, the President's control of officials depends on the structure of congressional legislation.

Although I am quite sympathetic with the congressional regulation theory, a major point of this Article is to defend congressional regulation of presidential action not through an argument that the Constitution has always meant that Congress may regulate in this fashion, but on the narrower argument, that even if in the nondelegation doctrine days Congress could not constitutionally regulate presidential control of agency officials or reject presidential action by a majority vote of both Houses, in the post-nondelegation doctrine world such congressional actions restore a proper balance of powers consonant with the framers' view of checks and balances. ${ }^{16}$

(The second half of the Necessary and Proper Clause "assigns to Congress alone the responsibility to say by law what additional authority, if any, the executive and the courts are to have beyond that core of powers that are indispensable, rather than merely appropriate, or helpful, to the performance of their express duties under articles II and III of the Constitution.").

${ }^{16}$ The closest positions to mine in the legal literature are found in Justice White's dissent in INS $v$ Chadha, 462 US 919, 984-87 (1983), and in two articles, one by Peter Shane and one by William Eskridge, Jr. and John Ferejohn. Peter M. Shane, Independent Policymaking and Presidential Power: A Constitutional Analysis, 57 Geo Wash L Rev 596 (1989); Eskridge and Ferejohn, 80 Georgetown L J 523 (cited in note 8). Although all are concerned with rebalancing power after the collapse of the nondelegation doctrine, White's focus in Chadha is on congressional efforts to recapture power lost through delegation. To a great extent, see Section IV for the exception, I disagree with White's position upholding legislative vetoes. See Section III.A. I have no real quarrel with Shane's position, which, rather briefly, focuses properly on the need to diffuse power between the branches. See Shane, 57 Geo Wash L Rev at 621-22.

Eskridge and Ferejohn devote most of their article to game theoretic analysis of lawmaking power in the post-New Deal era and spend relatively little time on evidence of what the framers thought or on the independent agencies issue. Furthermore, Eskridge and Ferejohn support broader congressional control of delegated power than I do-they support the legislative veto without any of the caveats I suggest in Section IV, and they support congressional control over officials exercising executive power and thus criticize Bowsher $v$ Synar, 478 US 714 (1986), the result of which I support in Sections III.A.1 and III.B.2. See Eskridge and Ferejohn, 80 Georgetown L J at 545-47. 


\section{Assumptions of the Project}

The argument I advance below is based on a theory of constitutional interpretation that takes the framers seriously, but metaphorically rather than literally. That is, I suggest that although we must adhere to the framers' basic principles, the proper application of these principles sometimes looks quite different today than it would have looked two hundred years ago. I therefore follow a fairly well-accepted method of constitutional interpretation, which, following Lawrence Lessig and others, one might best call "translation." "This method raises a set of questions that I shall deal with in this Section: Why should we care at all about the framers' principles? If we should care, why should we translate principles rather than follow a more literal form of originalism? If we agree that translation is an appropriate method of constitutional reading, then which framers' principles are relevant, and which should be translated, rather than jettisoned? After sketching some responses to these questions, I will answer some questions specifically related to the project at hand: Is there a structural constitutional principle offended by presidential lawmaking, either empirically or theoretically, that requires structural adjustment? If so, how should we enforce this structural constitutional norm?

The framers' principles should matter to us, at least to some degree. This is commonly accepted, although often for the insufficient reason that attention to original constitutional principles is needed to constrain judicial interpretation. I agree that some constraint on the legal imagination is important, that regardless of one's theory of how constraints actually work, it is important for governmental officials-both elected and unelected-to act as if constraints matter, to seek to justify their constitutional exegesis through a widely accepted set of interpretive principles. I also agree that what the framers thought is always a proper starting

In addition to White, Shane, and Eskridge and Ferejohn, Cass Sunstein has twice very briefly suggested the position I elaborate here, but seemed, in the latter piece, to lean toward the chain of command position. See Cass R. Sunstein, Changing Conceptions of Administration, 1987 BYU L Rev 927, 945; Cass R. Sunstein, Constitutionalism After the New Deal, 101 Harv L Rev 421, 499-500 (1987). Now, upon closer consideration, Sunstein has firmly adopted the view that independent agencies should be deemed unconstitutional in many circumstances because of accountability and coordination concerns. See Lawrence Lessig and Cass R. Sunstein, The President and the Administration, 94 Colum L Rev 1 (1994).

17 See Lawrence Lessig, Fidelity in Translation, 71 Tex L Rev 1165 (1993). See also Paul Brest, The Misconceived Quest for the Original Understanding, 60 BU L Rev 204, 218-21 (1980); sources cited in Lessig, 71 Tex L Rev at 1171 n 32. 
point for such interpretation. But by focusing on the way in which originalism conserves authority, this obsession with constraints neglects the important role originalism can play in constructing constitutional identity. Through the interpretive process of looking backward through the eras from our time to the framers', we construct our identity as a specific people-the people of the United States of America-united under our Constitution. ${ }^{18}$ That identity is not predetermined, or somehow existing "out there" waiting to be discovered by an interpreter. ${ }^{19}$ At any given time, "We," the citizens of the United States, are not bound together by some magical, external glue, but rather by practices that allow us to think of ourselves as a people, both at one time and over time. The proper use of originalism in constitutional law is only one of those practices that help us to ward off the natural entropy, or societal schizophrenia, that would otherwise result. By telling the narrative of who we have been, as a people, we construct, out of our otherwise randomly connected lives, a meaningful story of unity and identity.

All well and good, one might say, but why should we translate the framers' principles rather than apply them as the framers meant to apply them, unless a properly ratified amendment has intervened? The answer is that sometimes we can be faithful to the framers' principles only by applying them differently from how the framers would have applied them. If certain elements of our constitutional structure shift, and other elements are thought worth preserving, then we often must think of those other elements in a new way. Thus, in this Article, I argue that to preserve in the late twentieth century what the framers meant by dividing legislative from executive power, we must reconceptualize the congressionalpresidential power structure. In so doing, we will not be altering the Constitution, but rather maintaining its identity over time. ${ }^{20}$

But what, precisely, were the framers' principles regarding the division of congressional and presidential power? And which of these principles should we deem so fundamental as to merit preservation through a sea of other structural changes? In Section II, I argue that the best reading of the Convention Debates and The Federalist Papers reveals a heavy emphasis on creating not simply a strong executive, but rather a strong enough executive to check

18 See Bruce Ackerman, We the People 1: Foundations 36-37 (Harvard, 1991).

19 Compare Sanford Levinson, Constitutional Faith 191 (Princeton, 1988).

20 Compare Ackerman, We the People at 105-30, 159-62 (referring to the need to synthesize principles from our first republic, the framing. period, with our third republic, the post-New Deal era). 
what the framers expected to be an overreaching legislature. Further, I argue that the framers explicitly considered and rejected the possibility of presidential lawmaking. Moreover, I explain in Sections II and III that these concerns trumped concerns about accountability, as the framers consciously chose a structure in which accountability would be sacrificed for divided power.

In Sections III and IV, I argue that in an era of presidential lawmaking, preserving the framers' core principle of dividing legislative from executive power requires other structural adjustments. Perhaps, though, we should simply accept presidential lawmaking without other structural shifts, allowing the strong division of powers principle to wane; perhaps, to encourage efficiency and energy in government, we should accept a form of government in which one branch has tremendous executive and legislative power. To me this seems the wrong course. As I discuss in Section II, the framers themselves accepted only a certain measure of efficiency and energy, sacrificing both to the bedrock principle of dividing power. Moreover, we should still be deeply troubled by concentrated governmental power. Lawmaking and executing should not be done by the same branch of government. If the body that makes law also controls its execution, it can effectively tailor the laws to help itself and its friends and hurt its enemies. ${ }^{21}$ It can thwart the virtue of impartial, general lawmaking by rendering it a tool for singling out. Keeping the executive independent from the legislature helps ensure that the lawmaking body operates from behind a veil of ignorance; ${ }^{22}$ then the lawmaking body will know that it and its friends must be subject to the laws just as its enemies will be. Thus, executive independence provides an incentive for the lawmaking body to reduce the harshness of legislation; the benefits from such reduced harshness will accrue to all citizens.

Moreover, concentrations of power in any branch of government or particular governmental official should be avoided, even beyond the specific case of blended legislative and executive power. Although this Article focuses on checks and balances between the President and Congress, ${ }^{23}$ it is important to realize that the core

${ }^{21}$ On the norm of impartiality and the rule against self-interested action, see Cass $R$. Sunstein, The Partial Constitution 19, 27, 352 (Harvard, 1993).

22 See John Rawls, A Theory of Justice 136-37 (Harvard, 1971) ("I assume that the parties are situated behind a veil of ignorance. They do not know how the various alternatives will affect their own particular case and they are obliged to evaluate principles solely on the basis of general considerations.").

2s This Article at times refers to "checks and balances" rather than "separation of powers," but certainly both concepts are relevant to my argument. Dividing power among gov- 
value of multiple repositories of power that the citizens are sovereign and their delegated power must be fractured among various governmental actors-is central as well to both judicial review and federalism. As Hamilton made clear in Federalist 78, judicial review was intended to provide a check against self-judging by the political branches. ${ }^{24}$ Furthermore, the structure of federalism was intended to ensure that the citizens had multiple governmental repositories, at varying levels of locality, into which to delegate powers. ${ }^{25}$

To be sure, the framers' argument against concentrated governmental power was based on a prediction derived from a particular theory of human nature-that human beings holding delegated authority will tend, too often, to use that authority to advance their own interests, rather than the "public good." Federalist 10 is the classic statement of this position. ${ }^{26}$ Because all governmental agents can be expected to use their power to advance such factional interests, the solution is not to reform the nature of human behavior, but rather to set interest against interest, faction against faction, and hope that the resulting struggles will weed out the most self-promoting governmental actions. If today we continue to accept the view that those holding the citizens' delegated power must be carefully checked, then there is good reason for a continuing focus on diffusing power.

Diversifying the voices heard in government not only helps to prevent one point of view from becoming too strong, but also promotes the affirmative goal of democratizing governmental decisionmaking. ${ }^{27}$ Diversification expands the portfolio of interests that

ernmental officials is the core concern; a system of checks and balances, rather than a system in which each branch exercises power on its own, ensures against the inflation of power in any one branch. See Federalist 47 and 48 (Madison) in Clinton Rossiter, ed, The Federalist Papers 300, 308 (Mentor, 1961). Compare M.J.C. Vile, Constitutionalism and the Separation of Powers 120-21 (Oxford, 1967) ("[I]n the America of 1787 the doctrine of the separation of powers was modified, tempered, buttressed even, by the theory of checks and balances drawn from the older conception of English constitutional theory, but it remained itself firmly in the centre of men's thoughts as the essential basis of a free system of government.").

24 Federalist Papers at 464.

${ }^{25}$ See New York v United States, 112 S Ct 2408, 2431, 2434 (1992); Samuel H. Beer, To Make A Nation: The Rediscovery of American Federalism 383-88 (Harvard, 1993); Michael W. McConnell, Federalism: Evaluating the Founders' Design, 54 U Chi L Rev 1484, 1493-1507 (1987), reviewing Raoul Berger, Federalism: The Founders' Design (Oklahoma, 1987); Andrzej Rapaczynski, From Sovereignty to Process: The Jurisprudence of Federalism After Garcia, $1985 \mathrm{~S}$ Ct Rev 341, 354, 357.

${ }^{26}$ (Madison), in Federalist Papers at 77.

${ }^{27}$ See sources cited in note 25. 
will be represented by governmental agents. Just as the expansion of citizen involvement in government through aggressive assertion of speech, press, petition, and voting rights broadens the scope of positions represented during public debate, so too can an enlarged dialogue within the government serve this democratizing end. In this way, we can see the important analogy between the rights and the powers contained in the Constitution. For just as the assertion of individual rights against the government helps to diffuse power "vertically"-from the government back to the authorizing citizens-so does the fracturing of power among governmental agents diffuse power "horizontally"-within government itself. ${ }^{28}$

Finally, is the core framers' principle of ensuring that neither Congress nor the President grows too strong really offended by presidential lawmaking, or does the modern Congress have enough power devices to counteract the President? Even if presidential power is ascendant, have We the People ratified this shift in power, so as to obviate the need for other structural moves that weaken the presidency? And even if we conclude that the modern presidency has vastly increased power relative to Congress, and that the populace has not clearly rejected the divided power norm, what is the proper way of enforcing that norm? Should we enforce the nondelegation doctrine? Should we require Congress to delegate less often or more specifically? Or is it proper to permit Congress to enact other pieces of framework legislation to counteract its delegations of lawmaking power?

Congress indeed has many tools at its disposal, including oversight and attendant contempt sanctions; cutting agency funding, staff, and jurisdiction; and various other legislative maneuvers to impede presidential initiatives. Furthermore, in many instances congressional committees and subcommittees are engaged in power struggles with secretaries and undersecretaries of cabinet departments. But much of this power has always existed; it is not new power developed to counteract increased presidential lawmaking. Moreover, even though the political science literature offers some support for the proposition that congressional pressure and influ-

${ }^{28}$ For discussions of the need to interrelate the structural and rights portions of the Constitution, see Akhil Reed Amar, The Bill of Rights as a Constitution, 100 Yale L J 1131 (1991); Brown, Separated Powers and Ordered Liberty, 139 U Pa L Rev 1513 (cited in note 9); Geoffrey P. Miller, Rights and Structure in Constitutional Theory, 8 Social Phil \& Policy 196 (Spring 1991). On the centrality of multiple repositories of power to the American system of government, see Sunstein, The Partial Constitution at 23, 135, 253 (cited in note 21). 
ence might overwhelm the bureaucrats, ${ }^{29}$ some scholars have argued that congressional influence is not that strong. ${ }^{30}$ In any event, I am not addressing all possible legislative branch versus executive branch battles. Especially in Section IV, I am focusing on those cases in which the President, or the President's delegate, faces off against Congress as an institution..$^{31}$ Those cases do raise the problem of concentrated power in the President, and they require us to determine what sort of congressional response should be deemed sufficient to check such power. Most importantly, my argument in both Sections III and IV is based on the simple and incontestable fact that the post-New Deal presidency has substantially greater policy-making power than the pre-New Deal presidency, both in absolute terms and relative to Congress.

One might accept the factual statement that presidential policy-making power has increased substantially relative to congressional policy-making power, but maintain that the American people have authorized this constitutional change along with the

${ }^{29}$ See Randall L. Calvert, Mark T. Moran, and Barry R. Weingast, Congressional Influence Over Policy Making: The Case of the FTC, in Mathew D. McCubbins and Terry Sullivan, eds, Congress: Structure and Policy 493 (Cambridge, 1987); Mathew D. McCubbins and Talbot Page, $A$ Theory of Congressional Delegation, in McCubbins and Sullivan, Congress: Structure and Policy at 409; Barry R. Weingast, The Congressional-Bureaucratic System: A Principal Agent Perspective (With Applications to the SEC), 44 Pub Choice 147, 148 (1984); Richard E. Wiley, "Political" Influence at the FCC, 1988 Duke L J 280, 282.

30 See Terry M. Moe, An Assessment of the Positive Theory of 'Congressional Dominance', 12 Legis Studies Q 475, 476-77 (1987) (criticizing congressional dominance theories); Calvert, et al, Congressional Influence, in McCubbins and Sullivan, Congress: Structure and Policy at 493-94 (acknowledging dispute in the literature over the degree of congressional control of regulatory agencies: "Though the possibility of congressional control sometimes gets support from casual observation or case studies, attempts to detect and measure it systematically have not been uniformly convincing."). Weingast points out that the literature is "dominated" by the conclusion that "Congress yields little influence over agency decisions" because the literature improperly focuses on overt congressional oversight rather than on more subtle threats of sanctions operating through the power of committee and subcommittee members. See Weingast, 44 Pub Choice at 151-58. Both the Weingast study and the Calvert, Moran and Weingast study examine congressional influence on independent agencies (the SEC and the FTC), and not congressional influence on executive agencies (which I focus on in Section IV). Also consider that for threats of committee members to be credible, agencies must perceive that the members will be able to limit their funds or jurisdiction via the Article I, Section 7 process, which requires the President's signature and thus collaboration, or a veto override, which is difficult to accomplish.

${ }^{31}$ See Strauss, 84 Colum L Rev at 578-79, 596-97, 639 (cited in note 14), arguing that a stricter separation of powers analysis should be applied to actions by the named heads of the three branches, while a looser functionalism is appropriate when dealing with agents of the named heads. Compare Geoffrey P. Miller, From Compromise to Confrontation: Separation of Powers in the Reagan Era, 57 Geo Wash L Rev 401, 407 (1989) (focusing on President-Congress battles). 
increased concentration of power in the President. On this view, we must relax our attachment to the framers' principle of divided power. This seems to me an incorrect reading of the demise of the nondelegation doctrine. Although We the People have clearly accepted greater presidential policy making to ensure that the federal government can effectively handle the intricate array of national and international dilemmas, there has been no accompanying rejection of congressional balancing initiatives. To be sure, as I discuss in Section III, the Court has invalidated some of these framework laws, but there has been no political ratification by the electorate of either these invalidations or of rebalancing laws in general. ${ }^{32}$ The reasons stated above for continuing to attach great importance to the principle of nonconcentrated power-the vice of power agglomeration and the virtue of multiple voices-are still good reasons today, reasons that resonate throughout our politics. ${ }^{33}$

If one agrees that increased presidential lawmaking is a problem of constitutional magnitude, one might still reject my solution, a solution that permits Congress to enact countervailing framework legislation. Instead, one might propose either (a) that enforcement of the nondelegation doctrine be revived, or (b) that Congress solve the problem, when it chooses to, not through framework measures such as independent agencies or concurrent resolutions that trump entrenching vetoes, but rather by delegating less often or more specifically.

These seem to me the wrong answers. To be sure, many have urged reviving enforcement of the nondelegation doctrine. ${ }^{34}$ But

32 See generally Ackerman, We the People (cited in note 18) (certain political ratifications can constructively amend the Constitution even though the Article $\mathrm{V}$ amendment procedures are not used).

ss As Barry Karl has observed, Congress prevented Roosevelt from reorganizing the federal bureaucracy to give the President sweeping control of central planning. "When Congress abolished [the National Resources Planning Board] in 1943 over Roosevelt's objections, it did not simply conclude it by refusing to continue its funding but took every step it could to assure that the experience be blotted from the record and not permitted to reappear." Barry D. Karl, Constitution and Central Planning: The Third New Deal Revisited, $1988 \mathrm{~S}$ Ct Rev 163, 164-65.

s4 See, for example, Eskridge and Ferejohn, 80 Georgetown L J at 535, 561 (cited in note 8); Joel L. Fleishman and Arthur H. Aufses, Law and Orders: The Problem of Presidential Legislation, 40 L \& Contemp Probs 1, 43 (Summer 1976); Peter H. Aranson, Ernest Gellhorn, and Glen O. Robinson, $A$ Theory of Legislative Delegation, 68 Cornell L Rev 1, 63-67 (1982); Paul Gewirtz, The Courts, Congress, and Executive. Policy-Making: Notes on Three Doctrines, 40 L \& Contemp Probs 46, 53, 56-57 (Summer 1976); Theodore J. Lowi, The End of Liberalism: The Second Republic of the United States 300-01 (Norton, 2d ed 1979); Theodore J. Lowi, Two Roads to Serfdom: Liberalism, Conservatism and Adminis- 
the nondelegation doctrine would be hard to enforce systematically. ${ }^{35}$ The standard "test" for delegation-Congress must "lay down by legislative act an intelligible principle to which the person or body authorized to [act] is directed to conform"36 - might produce some easy cases if applied seriously, but there would be many more hard cases. Also, the Court's invalidation of marginal cases of congressional delegation could produce the sort of outcry that followed invalidation of provisions of the National Industrial Recovery Act of $1935 .{ }^{37}$

Although there is some common sense to suggesting that Congress can correct any imbalance of power by giving away less of it, this solution should be rejected as well. Initially, rejecting restructuring framework legislation in favor of congressional self-help does not solve the problem of vague delegations already on the books, because repealing delegations of power to the President would often require a veto override. Secondly, the cost and necessary incompleteness of legislation renders the congressional selfhelp argument problematic. Even if restructuring legislation were invalidated, thus giving Congress a greater incentive to legislate more precisely, problems would still arise that fall within a law's

trative Power, 36 Am U L Rev 295, 296-329, 319 (1987); Alan B. Morrison, A Non-Power Looks at Separation of Powers, 79 Georgetown L J 281, 300 (1990); David Schoenbrod, The Delegation Doctrine: Could the Court Give it Substance?, 83 Mich L Rev 1223, 1228 (1985); David Schoenbrod, Separation of Powers and the Powers that Be: The Constitutional Purposes of the Delegation Doctrine, 36 Am U L Rev 355, 366-67 (1987); J. Skelly Wright, Review: Beyond Discretionary Justice, 81 Yale L J 575, 582-87 (1972), reviewing Kenneth C. Davis, Discretionary Justice: A Preliminary Inquiry (Louisiana State, 1969). See also Charles L. Black, Jr., The Working Balance of the American Political Departments, 1 Hastings Const L Q 13, 19 (1974) ("Congress ought to develop a simple taboo on delegation to the president of power to make total policy with respect to matters of prime national concern.").

${ }^{35}$ See, for example, Mistretta $v$ United States, 488 US 361, 415-16 (1989) (Scalia dissenting); Harold H. Bruff, Judicial Review and the President's Statutory Powers, 68 Va L Rev 1, 27 (1982); William N. Eskridge, Jr., and John Ferejohn, Making the Deal Stick: Enforcing the Original Constitutional Structure of Lawmaking in the Modern Regulatory State, 8 J L Econ \& Org 165, 172 (1992); Pierce, 64 Tex L Rev at 493-97 (cited in note 14); Richard J. Pierce, Jr., Political Accountability and Delegated Power: A Response to Professor Lowi, 36 Am U L Rev 391, 392-403 (1987); Richard B. Stewart, The Reformation of American Administrative Law, 88 Harv L Rev 1667, 1679, 1695-96 (1975); Richard B. Stewart, Beyond Delegation Doctrine, 36 Am U L Rev 323, 324-29 (1987).

${ }^{38}$ J. W. Hampton, Jr., \& Co. $v$ United States, 276 US 394, 409 (1928), quoted in Touby $v$ United States, 111 S Ct 1752, 1756 (1991).

${ }^{37}$ See, for example, Panama Refining Co. $v$ Ryan, 293 US 388, 430 (1935) (invalidating a provision of the National Industrial Recovery Act of 1933 on nondelegation doctrine grounds); A.L.A. Schechter Poultry Corp. v United States, 295 US 495, 541-42 (1935) (same, and invalidating other provisions on Commerce Clause grounds). For an article showing the virtues of delegation, see Jerry L. Mashaw, Prodelegation: Why Administrators Should Make Political Decisions, 1 J L Econ \& Org 81 (1985). 
jurisdiction but that are not resolved by the law. Not only is it too costly to address all foreseeable problems, but also some problems are unforeseeable at the time the legislation is written. ${ }^{38}$ It is incredibly expensive to write legislation that deals with all problems in a given area. Just as in contract law we do not expect the parties to write contracts that cover everything, because of the cost, ${ }^{30}$ so should we be realistic about the cost of writing more complete legislation. Additionally, if, despite diligent congressional efforts to be comprehensive, an unaddressed problem arises, the President would have total control to create policy in that lacuna, absent a constitutionally legitimate framework device to temper such presidential power.

Finally, let me acknowledge that independent agencies and authoritative concurrent resolutions opposite entrenching vetoes might seem second-best solutions to the problem of delegating legislative power to the executive branch. Perhaps the best solution is the legislature doing all the legislating, and a strongly unitary executive doing all the executing. But to insist on this seems improperly nostalgic. In particular, the time for serious constitutional debate over whether the nondelegation doctrine should be enforced was when the Court first relaxed enforcement of it many years ago. ${ }^{40}$ Perhaps we must adjust not by asking for a return to Eden, but by accepting the delegation of legislative power to the executive branch-and, as part of the package, the fracturing of the executive branch and an appropriate countermeasure to the entrenching presidential veto. Just as Madison recognized that the American structure of government was not a perfect system, but rather "a republican remedy for the diseases most incident to re-

ss See American Power \& Light Co. v SEC, 329 US 90, 105 (1946) ("Necessity [ ] fixes a point beyond which it is unreasonable and impractical to compel Congress to prescribe detailed rules ....").

"See Ian Ayres and Robert Gertner, Filling Gaps in Incomplete Contracts: An Economic Theory of Default Rules, 99 Yale L J 87, 92 (1989); Ian Ayres and Robert Gertner, Strategic Contractual Inefficiency and the Optimal Choice of Legal Rules, 101 Yale L J 729, 732 n 12 (1992).

to New York Central Securities Corp. $v$ United States, 287 US 12, 24-25 (1932); Federal Radio Commission v Nelson Bros. Bond \& Mortgage Co., 289 US 266, 285 (1933); FCC v Pottsville Broadcasting Co., 309 US 134, 138 (1940); Yakus v United States, 321 US 414, 425-27 (1944); American Power \& Light, 329 US at 104-06 (1946); Federal Energy Administration v Algonquin SNG, Inc., 426 US 548, 558-60 (1976). See also Mistretta, 488 US at 413-16 (1989) (Scalia dissenting); Henry P. Monaghan, The Protective Power of the Presidency, 93 Colum L Rev 1, 5 (1993). But see Currie, $1986 \mathrm{~S}$ Ct Rev at 27-30 (cited in note 14) ("[I]ndividual decisions over the years may have stretched the nondelegation doctrine; but -it remains the law that delegated authority must be confined in order to preserve the responsibility of the legislature to make basic policy."). 
publican government," 41 so we should accept post-New Deal restructuring framework legislation not as the best of all possible worlds, but as the best given our world.

In sum, we should accept independent agencies and authoritative concurrent resolutions (in limited situations) as appropriate ways for Congress to exercise its responsibility of attending to the constitutional norm of divided power. The Constitution gives Congress the power "To make all Laws which shall be necessary and proper for carrying into Execution . . . all . . . Powers vested by this Constitution in the Government of the United States, or in any Department or Officer thereof." 42 Just as we might see the nondelegation doctrine as a constitutional norm that the Court will underenforce but that Congress may (and should) pay attention to, so should we see the divided power norm as one that Congress plays a primary role in policing. Thus, the Court should not order Congress to create independent agencies or to pass authoritative concurrent resolutions opposite entrenching presidential vetoes, but if Congress chooses to do either, the Court should respect the action as congressional enforcement of the divided power norm.

\section{The Decision of 1787: Dividing and Balancing Legislative AND Executive Powers}

Some have argued that the framers of the Constitution established a strong executive to combat a mischievous legislature, and thus that twentieth century congressional attempts at regulating the executive run afoul of the original structure. ${ }^{43}$ Some evidence from the framing materials does reveal a focus on limiting congressional power. But when one examines the entire picture, one discovers a concern not with establishing a strong executive alone, but rather with establishing a strong enough executive to keep a strong legislature in check. The bottom line was not strength in the executive, but rather balance between the branches, secured through a division of power.

\footnotetext{
4 Federalist 10, in Federalist Papers at 84 (cited in note 23).

42 US Const, Art I, § 8, cl 18.

43 See note 14 .
} 
A. Pre-1787: Balance in Theory, Concern with Executive Tyranny in Practice

American political writers in the late eighteenth century were well versed in Montesquieu, ${ }^{44}$ who in 1748 had argued:

When the legislative and executive powers are united in the same person, or in the same body of magistrates, there can be no liberty; because apprehensions may arise, lest the same monarch or senate should enact tyrannical laws, to execute them in a tyrannical manner.

The legislative body being composed of two parts, they check one another by the mutual privilege of rejecting. They are both restrained by the executive power, as the executive is by the legislative.

These three powers should naturally form a state of repose or inaction. But as there is a necessity for movement in the course of human affairs, they are forced to move, but still in concert. ${ }^{45}$

For the colonists, the potential for abuse of delegated, governmental power was of central importance. As Bernard Bailyn has written, "[m]ost commonly the discussion of power centered on its essential characteristic of aggressiveness: its endlessly propulsive tendency to expand itself beyond legitimate boundaries." gated public power was not in itself evil; "[w] hat made it so, what turned power into a malignant force, was not its own nature so much as the nature of man-his susceptibility to corruption and his lust for self-aggrandizement."47

The Americans sought to thwart the self-aggrandizing tendencies of governmental agents by turning to British principles of constitutionalism. In England, the various elements of society had "entered [into government] simultaneously, so to speak, in a balanced sharing of power. The functions, the powers, of government were so distributed among these components of society that no one of them dominated the others." ${ }^{\text {"8 }}$ But the colonists transmuted the

14 See, for example, Bernard Bailyn, The Ideological Origins of the American Revolution 27 (Harvard, 1967). See also Gordon S. Wood, The Creation of the American Republic 152 (Norton, 1969).

ts Baron de Montesquieu, The Spirit of the Laws 151-52, 160 (Hafner, Thomas Nugent trans, 1949).

so Bailyn, Ideological Origins at 56.

67 Id at 58-59.

48 Id at 70. 
British system of mixed government based on social classes to a government in which three branches, the legislative, executive, and judicial, would check each other, regardless of the social class from which the officials were drawn.

Thus, the revolutionary colonists established balance of powers among their governmental agents as the key to liberty, at least in theory. The problem was the practice. As Gordon Wood has explained, "what more than anything else makes the use of Montesquieu's maxim in 1776 perplexing is the great discrepancy between the affirmations of the need to separate the several governmental departments and the actual political practice the state governments followed."49 Both before and after the Revolution, state legislatures "dominat[ed] . . . the other parts of the government." Indeed, the central practical concern of the colonists seems to have been prevention of power accruing not to one branch, but to one person. Again, Wood explains:

When Americans in 1776 spoke of keeping the several parts of the government separate and distinct, they were primarily thinking of insulating the judiciary and particularly the legislature from executive manipulation. Even though the governors in most of the new constitutions no longer controlled the appointment of executive officials, so infecting and so incompatible with the public liberty or the representation of the people was magisterial power believed to be that the Ameri- cans felt compelled to isolate their legislatures from any sort of executive influence or impingement, thus setting American constitutional development in an entirely different direction from that of the former mother country. ${ }^{51}$

B. The Constitution of 1787: Reclaiming Balance through Creating a Strong Enough Executive

But all was not well with the governmental structures in place during the 1780s. Many state legislatures succumbed to pure majoritarian tendencies; rather than reflecting upon greater notions of the public good, state legislatures confiscated property, issued paper money, and eliminated debts. To be sure, these laws were "enacted by legislatures which were probably as equally and fairly representative of the people as any legislatures in history,"

19 Wood, Creation of the American Republic at 153 (cited in note 44).

${ }^{60} \mathrm{Id}$ at 155.

${ }^{62}$ Id at 157-58. 
but the problem was that government was acting too easily, interfering with property rights without sufficient structural encumbrances. ${ }^{52}$ And this excess government was all the product of legislatures; "[t]he governors were mere ciphers, almost totally dependent on the legislatures, with little or no power to resist or control the political and social instability."

Thus, although providing greater power to the national government was the framers' central concern when they met in Philadelphia in the spring and summer of 1787, the framers of our Constitution also sought to ensure against future legislative abuse. One method was to establish a strong executive power, vested not in a commission or group of people, but in one person, the "President." In the States, the idea of checks and balances was already being "made truly reciprocal by those seeking new justifications for strengthening the magisterial parts of the government at the expense of the legislature." Now it was time for the United States national government to be restructured as well.

All agree that the framers deliberately chose a unitary rather than plural executive at least in a limited sense, that is, they consciously decided that one person, rather than a team of people, should be atop the executive branch. The hard questions are: What precisely was the nature of the "executive" that the framers established? What relevance do the framers' decisions about the executive branch have for us today? In discussing the debates of the 1787 Constitutional Convention and The Federalist Papers, I shall offer two theories. The first holds that although the framers chose one person to head the executive branch, they did not intend to prohibit the establishment of other executive positions that would be free from ultimate presidential control. In other words, the framers' concept of unitariness was itself more limited than contemporary advocates of the unitary executive would allow. The second theory acknowledges (at least for purposes of discussion) that the framers' concept of unitariness was expansive, but holds that such a concept was inextricably bound with a severely limited concept of executive power. Against the backdrop of the framers' overarching fear of the concentration of legislative and executive power, understanding the framers' concept of the unitary executive as part of a package that included sharply circumscribed executive

\footnotetext{
52 Id at 404.

ss Id at 407 .

ss Id at 449 .
} 
powers will allow us to justify-on originalist terms-the fracturing of the executive when its powers are significantly expanded. ${ }^{\circ 5}$

\section{The Convention debates.}

I shall break down the relevant debates into four categories: (a) Executive number, (b) Executive power, (c) Executive election and tenure, and (d) Ineligibility and Incompatibility Clauses.

a) Executive number. The Virginia Plan that formed the basis for initial discussion at the Convention did not specify how many people should constitute the "National Executive." On June 1, 1787, the delegates began the debate over whether a unitary or plural executive should be established; the vote was postponed. ${ }^{67}$ The debate continued on June 2; the vote was postponed again. ${ }^{58}$ The debate continued on June 4 , and the vote that day was 7 States to 3 for a unitary executive. ${ }^{89}$

The debates on executive number suggest that the delegates focused only on how many people should hold the top spot in the executive branch, and that they would have thought it perfectly consistent to allow, in the future, the establishment of other executive officials not removable by the President at his discretion. A report of a statement by Wilson-one of the most eloquent and important members of the Convention, and a strong supporter of a unitary executive-is crucial here:

The tranquility not less than the vigor of the government he thought would be favored by [a unitary executive]. Among three equal members, he foresaw nothing but uncontrolled, continued, and violent animosities . . . . In courts of justice there are two sides only to a question. In the legislative and executive departments, questions have commonly many sides. Each member therefore might espouse a separate one and no two agree. ${ }^{60}$.

ss See Section III.

${ }^{58}$ Max Farrand, ed, I The Records of the Federal Convention of 178721 (Yale, 1966). As cited throughout this Article, quotations from these debates have been altered to comport with modern usage.

${ }^{37}$ Id at $64-66$.

s8 Id at 89.

${ }^{89}$ Id at 96-97. The unitary executive was approved again on July 17, without dissent, and again on July 26. Max Farrand, ed, II The Records of the Federal Convention of 1787 29, 121 (Yale, 1966).

${ }^{60}$ Farrand, I Records at 96 . In arguing that judicial appointments should be made by the already-established unitary executive, Wilson made a similar point about the need to 
Wilson's concern was with decisional chaos if power to decide particular issues were given to more than one person. Whether a lower-level official could be given power to make some discrete decisions independently of the President is a different matter, apparently not considered by the Convention delegates.

Apart from this evidence supporting a limited concept of unitariness, there is great reason to believe that whatever their concept of unitariness, the supporters of a unitary executive also had a concept of limited executive power. Although these delegates often invoked terms such as "responsibility," "administration,"62 "energy," executive were mentioned in the same breath as two other structural concerns. First, these qualities were needed to counter what was perceived to be a strong, impetuous legislature. As Wilson put it, unity in the executive is the "best safeguard against tyranny."6s Second, there was no reason to fear vesting executive power in one person because that executive power would be quite limited. This packaging point became important when advocates of a plural executive tried to evoke fears of a powerful unitary executive. Mason, for instance, was concerned that executive powers had not yet been fleshed out, that "there is a general tendency to a strong executive," and that "[i]f strong and extensive powers are vested in the executive, and that executive consists only of one person, the gov-

avoid the dangers peculiar to multi-member bodies: "Experience showed the impropriety of [ ] appointments by numerous bodies. Intrigue, partiality, and concealment were the necessary consequences. A principal reason for unity in the executive was that officers might be appointed by a single, responsible person." Id at 119 . Wilson also made a similar point in later opposing the New Jersey Plan's proposed plural executive: "In order to control the legislative authority, you must divide it. In order to control the executive you must unite it. One man will be more responsible than three. Three will contend among themselves till one becomes the master of his colleagues." Id at 254. Butler voiced an analogous concern about the problem of partiality in a plural executive: A unitary executive would be "most likely to answer the purpose of the remote parts. If one man should be appointed he would be responsible to the whole, and would be impartial to its interests. If three or more should be taken from as many districts, there would be a constant struggle for local advantages. In military matters this would be particularly mischievous." Id at 88-89. Gerry also noted that a plural executive would "be extremely inconvenient in many instances, particularly in military matters." Id at 97.

${ }^{61}$ Id at 65 (Rutledge); id at 65, 119, 254 (Wilson); id at 88 (Butler); id at 139 (King); id at 140 (Dickinson).

${ }^{62}$ Id at 65 (Rutledge).

${ }^{83}$ Id at 65 (Wilson); id at 140 (Dickinson).

of Id at 65 (Wilson); id at 140 (Dickinson).

ss Id at 66. 
ernment will of course degenerate . . . into a monarchy . . . ."BB Randolph, a strong opponent of the unitary executive, "regarded it as the fetus of monarchy."

In response, the supporters of a unitary executive downplayed the amount of power the executive would have. Their arguments, perhaps crucial to gaining a majority on the issue, reveal how consciously the issues of executive number and executive power were intertwined. For example, Rutledge advocated a unitary executive, but added that the executive should not have the "power of war and peace." 88 Again, the report of Wilson's comment is quite revealing:

He did not consider the prerogatives of the British monarch as a proper guide in defining the executive powers. Some of these prerogatives were of a legislative nature, among others that of war and peace etc. The only powers he conceived strictly executive were those of executing the laws, and appointing officers . . . . 9

b) Executive power. As indicated above, the supporters of a unitary executive predicated such support on an executive with sharply limited powers. In particular, the framers clearly understood that the executive would not exercise legislative powers.

On June 1, after the vote on executive number was first postponed, Madison suggested that defining executive power would help in the discussion on executive number. ${ }^{70} \mathrm{He}$ moved that the language regarding executive power read: "with power to carry into effect the national laws, to appoint to offices in cases not otherwise provided for, and to execute such other powers, not legislative nor judiciary in their nature, as may from time to time be delegated by the national legislature." The phrase "not legislative nor judiciary in their nature" was added to the proposed amendment after a suggestion "that improper powers might otherwise be delegated."72

${ }^{66}$ Id at 113 . See also id at 112 , noting that the principles of republican government require avoidance of monarchies.

${ }^{62}$ Id at 66 . See also id at 88.

${ }^{68}$ Id at 65.

${ }^{69}$ Id at 65-66. The concern about the executive having power over war and peace was maintained throughout the Convention. Thus, although the President is Commander-inChief, Congress has the power to declare war. See US Const, Art II, § 2, cl 1; US Const, Art I, § 8, cl 11; Farrand, II Reports at 318-19 (cited in note 59).

${ }^{20}$ Farrand, I Reports at 66-67 (cited in note 56).

71 Id at 67.

32 Id. 
There followed a motion to delete from Madison's motion all words after "provided for," because "they were unnecessary, the object of them being included in the "power to carry into effect the national laws'."73 Madison argued that the words after "provided for" should be retained to avoid "doubts and misconstructions," but the delegates voted 7-3 to approve Madison's motion only after striking the disputed language. ${ }^{74}$

This is an enormously helpful exchange, because it demonstrates that both sides of the debate over Madison's language understood that the executive would have executive powers only, and that the legislature could not delegate legislative (or judicial) powers to him. The delegation part of Madison's proposed language-as amended by the clarification that the legislature could delegate to the executive only executive power-was defeated not because the delegates thought it wrong, but because they deemed it redundant. The "power to carry into effect the national laws" already incorporated all powers that the legislature could properly delegate to the President, that is, executive powers but not legislative or judicial powers. ${ }^{75}$ This understanding of limited executive

73 Id.

"Id. The power "to carry into execution the national laws" was again approved, without dissent, on July 17. Farrand, II Reports at 32 (cited in note 59).

${ }^{75}$ The "carry into effect the national laws" language became, in the Committee of Detail, the Take Care Clause. I have reached this conclusion after examining various documents headed "Committee of Detail" compiled by Farrand. The first document "evidently represents the proceedings referred to the Committee of Detail." Farrand, II Reports at 129 n 1 . The section on executive power contains the language, "power to carry into execution the national laws." Id at 132. A later document (evidently from the Committee's delibera-

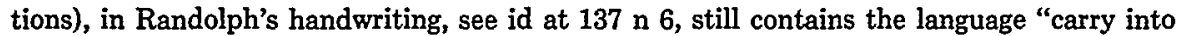
execution the national laws." Id at 145. Farrand's compilation then shows the "carry into effect the national laws" language becoming, in what one might deem a draft in progress: "(He shall take care to the best of his ability, that the laws) [It shall be his duty to provide" for the due and faithful execution of the laws] of the United States (be faithfully executed) [to the best of his ability]." Id at 171. This document is also evidently from the Committee's deliberations; it is in Wilson's handwriting with Rutledge's emendations (in brackets). Id at $163 \mathrm{n}$ 17. The Committee finally settled on "he shall take care that the laws of the United States be duly and faithfully executed." Id at 185. The language appears in the executive power section, where the "carry into execution the national laws" language had appeared. There is no other mention in the executive power section of carrying into execution (or effect) the national laws. Thus, it is reasonable to conclude that "carry into effect the national laws" had been transposed into (as it now reads) "take Care that the Laws be faithfully executed." US Const, Art II, § 3.

We can thus reach the following conclusion about the President's power to execute powers (nonlegislative and nonjudicial) delegated to him by Congress. Madison proposed that the Constitution expressly grant such power; this proposal was rejected because such power was already contained within the power to "carry into effect the national laws"; the power is, therefore, contained within the Take Care Clause, the successor to the power to "carry into effect the national laws." 
power buttressed the argument for a unitary executive-the executive should be strong enough to stand up to the legislature, but not so strong that one should fear monarchy.

c) Executive election and tenure. The delegates spent a lot of time on the questions of how the President should be elected, what the President's term of office should be, and whether he should be eligible for re-election. Throughout these discussions, there was an overarching concern for establishing an executive independent of legislative control. The need to avoid the concentration of legislative and executive power was paramount. As I argue in Sections III and IV, just as the framers fought the threat of the legislature's hegemony over both types of power, so must we fight the threat of the executive's hegemony over both types of power.

On July 17, when the draft still provided for presidential election by the legislature, McClurg moved to strike the President's 7year term, giving him tenure "during good behavior," to keep him from being "dependent for ever on the legislature." sponse, not necessarily supporting the good behavior motion, tried to ensure sufficient independence of the President from the legislature. He argued:

The executive could not be independent of the legislature, if dependent on the pleasure of that branch for a re-appointment. . . . [A] dependence of the executive on the legislature, would render [the legislature] the executor as well as the maker of laws; and then according to the observation of Montesquieu, tyrannical laws may be made that they may be executed in a tyrannical manner. . . . [ [t is] absolutely necessary to a well constituted republic that the [executive and legislative powers] should be kept distinct and independent of each other. ${ }^{77}$

The key, again, was establishing a sufficiently strong and independent executive in order to combat legislative tyranny. Madison again:

Experience had proved a tendency in our governments to throw all power into the legislative vortex. The executives of the States are in general little more than ciphers; the legislatures omnipotent. If no effectual check be devised for re-

${ }^{76}$ Farrand, II Reports at 33 (cited in note 59).

77 Id at 34-35. 
straining the instability and encroachments of the latter, a revolution of some kind or other would be inevitable. ${ }^{78}$

On July 19, Martin renewed a motion to make the President ineligible for re-election. ${ }^{79}$ Morris argued for a strong executive, and against Martin's motion: "One great object of the executive is to control the legislature. The legislature will continually seek to aggrandize and perpetuate themselves; and will seize those critical moments produced by war, invasion or convulsion for that purpose." then appeared up for grabs, and Madison argued: "There is the same and perhaps greater reason why the executive should be independent of the legislature, than why the judiciary should: a coalition of the two former powers would be more immediately and certainly dangerous to public liberty."81

On July 24, there was further debate on whether the legislature should elect the President. Morris argued, "If the legislature is to appoint, and to impeach or to influence the impeachment, the executive will be the mere creature of it."82 A key reason for the final move to the electoral college, and away from Congress electing the President, was this core checks and balances concern.

In sum, the debates over executive election and tenure help demonstrate that the framers were considering these issues only as a counterpoint to what they perceived would be a strong legislature, in large part because of the strong state legislatures they had witnessed during the Articles of Confederation. Had the framers feared a strong executive, it is the legislature they would have had to bolster, for their primary principle entailed neither a strong executive nor a strong legislature, but rather multiple repositories of the citizens' delegated power, so that no one repository of power could control.

d) Ineligibility and Incompatibility Clauses. The framers considered various options for rendering members of Congress ineligible to hold federal office. They settled on a system of strict ineligibility. Article I, Section 6, clause 2 of the Constitution contains two prohibitions. The Incompatibility Clause forbids federal officers from serving in Congress during their tenure of office. The

\footnotetext{
${ }^{78}$ Id at 35 . See also id at 74 .

79 Id at 52.

so Id.

82 Id at 56.

s2 Id at 103.
} 
Ineligibility Clause forbids members of Congress, for the period in which they were elected to Congress, from holding offices that were created or whose salary was increased during their congressional term. These provisions are textual markers of one of the framers' core checks and balances principles-that, with certain exceptions, ${ }^{83}$ executive and legislative power was not to be blended.

e) Summary. Each of the categories-Executive number, Executive power, Executive election and tenure, and the Ineligibility and Incompatibility Clauses-reveals that the framers operated from a concept of limited or conditional executive power. The framers started from Montesquieu's basic maxims regarding the need to separate executive power from legislative power. To limit legislative overreaching, they created a unitary executive not elected by Congress and prohibited simultaneous executive and legislative service. But to ensure that the executive itself would not become too powerful, thereby creating the same problem in a different guise, the framers were careful to limit executive power. Importantly, they assumed that although Congress could delegate executive powers to the executive, it could not delegate legislative powers.

These, then, were the checks and balances lessons from the debates. The framers had a concept of divided power that they implemented through particular conceptions. But if to be properly constitutionalist is to ensure that core concepts are maintained over time, then if certain parts of the picture change, others must be altered so that the whole can remain the same. That is the task taken up in Sections III and IV.

\section{The Federalist Papers.}

The Federalist Papers reinforce and add to the arguments made during the debates. The relevant Papers point to three conclusions: First, the framers operated from a core concept of dividing executive from legislative power to ensure against governmental tyranny. Second, the framers were careful to depict two faces of executive power: the executive must be strong enough to counter a strong legislature, but weak enough so monarchy need not be feared. Third, there is some evidence that the framers expected all

${ }^{83}$ Key exceptions include the President's veto power, US Const, Art I, \& 7, cl 2; his treaty-making role, US Const, Art II, $\S 2, \mathrm{cl} \mathrm{2}$; and the Senate's appointments role, US Const, Art II, \& 2, cl 2. 
federal administration to operate under the ultimate control of the President. Taking this third point seriously, a contemporary attempt to reduce the President's administrative control could not argue that the framers never envisioned total presidential administrative control. Rather, one would have to argue, as I do in Sections III and IV, that the premises of legislative and executive power have shifted. The framers operated from a premise of a strong legislature and an executive that would do no legislating, but today we start from a different premise.

a) Dividing powers. As do the debates, The Federalist Papers reveal an overarching concern with establishing. multiple repositories of power at the federal level, to ensure against the hegemony of any one actor or branch. Thus, Madison wrote in Federalist 47 , "[ $t]$ he accumulation of all powers, legislative, executive, and judiciary, in the same hands, whether of one, a few, or many, and whether hereditary, self-appointed, or elective, may justly be pronounced the very definition of tyranny."84 In Federalist 71, Hamilton rejected the suggestion that the President should serve at the legislature's discretion, according to its "prevailing current":

The republican principle demands that the deliberate sense of the community should govern the conduct of those to whom they entrust the management of their affairs; but it does not require an unqualified complaisance to every sudden breeze of passion, or to every transient impulse which the people may receive from the arts of men, who flatter their prejudices to betray their interests. ${ }^{85}$

While the legislature, the deliberative body, must make policy, it may not be entrusted with control of execution. As Hamilton wrote in Federalist 75:

The essence of the legislative authority is to enact laws, or in other words, to prescribe rules for the regulation of the society; while the execution of the laws and the employment of the common strength, either for this purpose or for the com-

B4 Federalist Papers at 301 (cited in note 23). See also Federalist 51 (Madison) at 320; Federalist 73 (Hamilton) at 442 (noting the concern that "the legislative and executive powers might speedily come to be blended in the same hands").

ss Federalist 71 at 432. 
mon defense, seem to comprise all the functions of the executive magistrate. ${ }^{86}$

b) A strong-enough executive. The implementation of these precepts in the United States of 1787 required the establishment of an executive strong enough to combat the legislature, which was "everywhere extending the sphere of its activity and drawing all power into its impetuous vortex." "87 In the key discussion in Federalist 48, Madison explained that the task at hand was to create an executive strong enough to combat an impetuous legislature.

[State constitution writers] seem never for a moment to have turned their eyes from the danger, to liberty, from the overgrown and all-grasping prerogative of an hereditary magistrate, supported and fortified by an hereditary branch of the legislative authority. They seem never to have recollected the danger from legislative usurpations, which, by assembling all power in the same hands, must lead to the same tyranny as is threatened by executive usurpations. . . . In a representative republic where the executive magistracy is carefully limited, both in the extent and the duration of its power; and where the legislative power is exercised by an assembly, which is inspired by a supposed influence over the people with an intrepid confidence in its own strength; which is sufficiently numerous to feel all the passions which actuate a multitude, yet not so numerous as to be incapable of pursuing the objects of its passions by means which reason prescribes; it is against the enterprising ambition of this department that the people ought to indulge all their jealousy and exhaust all their precautions. ${ }^{88}$

${ }^{88}$ Federalist 75 at 450 . See also Federalist 78 (Hamilton) at 465 ("The executive not only dispenses the honors but holds the sword of the community. The legislature not only commands the purse but prescribes the rules by which the duties and rights of every citizen are to be regulated.").

${ }^{87}$ Federalist 48 (Madison) at 309.

${ }^{88}$ Id (emphasis added). See also Federalist 49 (Madison) at 315-16 ("We have seen that the tendency of republican governments is to an aggrandizement of the legislative at the expense of the other departments."); Federalist 51 (Madison) at 322-23 ("In republican government, the legislative authority necessarily predominates"; the remedy is to establish a bicameral legislature as well as fortify the "weakness of the executive" through a veto, though qualified rather than absolute); Federalist 71 (Hamilton) at 433 ("It is one thing to be subordinate to the laws, and another to be dependent on the legislative body. . . . The tendency of the legislative authority to absorb every other has been fully displayed and illustrated by examples .... In governments purely republican, this tendency is almost 
Taken out of context, this statement might be used to support a strong executive always. But in context, it is both a response to the overreaching by state legislatures during the Articles period and a structural device to ward off such overreaching by the newly established Congress. The framers no more wanted monarchy than they wanted impetuous legislatures. This is evidenced by Madison's reference to "the same tyranny as is threatened by executive usurpations"; if the framers thought their problem was an executive branch that combined executive with legislative power, then their remedy would have been to weaken the President, and not Congress. Thus, we have Madison's classic statement in Federalist 51 of the overarching principle:

[T] he great security against a gradual concentration of the several powers in the same department consists in giving to those who administer each department the necessary constitutional means and personal motives to resist encroachments of the others.

[I]n all the subordinate distributions of power, [ ] the constant aim is to divide and arrange the several offices in such a manner as that each may be a check on the other . . . ${ }^{89}$

At the same time that they were explaining the need for an executive strong enough to check an impetuous legislature, the framers were mollifying those who feared an executive so strong as to be a monarch. Thus, Hamilton devoted papers 67 and 69 to explaining that the President has quite limited powers, especially when compared to the British King. ${ }^{90}$ This does not appear to have been mere bluffing. It is consistent with the evidence from the debates for the authors of The Federalist Papers to have expected a strong President acting within narrow confines.

c) A unitary executive. Federalist 70 contains the classic restatement of the virtues of a unitary executive, which were already elucidated during the debates: "energy," "decision, activity, secrecy, and dispatch," and "responsibility." As did the Convention delegates, Hamilton added that with multiple people at the

irresistible. The representatives of the people, in a popular assembly, seem sometimes to fancy that they are the people themselves, and betray strong symptoms of impatience and disgust at the least sign of opposition from any other quarter . . ..").

89 Federalist 51 at $321-22$.

oo Federalist 67 at 407 ; Federalist 69 at 415 .

91 Federalist 70 (Hamilton) at 423-24, 427. 
top of the executive branch, there is a "danger of difference of opinion," which can lead to animosity, dissension, and factions. It is fine to have a plural legislature, even if that means delay and factions, because deliberation is promoted; the output is a law, to which resistance is punishable, and thus time and deliberation are needed.92 Regarding the execution of the laws, things are different. For example, "[i]n the conduct of war, in which the energy of the executive is the bulwark of the national security, everything would be to be apprehended from its plurality."93 This supports the view that the framers' concept of unitariness was limited to a focus on the top of the executive branch; the fear was chaos from multiple decision makers. This view of unitariness does not foreclose empowering other officials with discrete areas of executive responsibility, and insulating them from ultimate presidential control.

But there is a passage from Federalist 72 that reveals a focus on unitariness as a broader principle, an expectation that all administration would ultimately come under presidential control. Much of governmental administration, Hamilton explained, falls to the executive:

The actual conduct of foreign negotiations, the preparatory plans of finance, the application and disbursement of the public monies in conformity to the general appropriations of the legislature, the arrangement of the army and navy, the direction of the operations of war-these, and other matters of a like nature, constitute what seems to be most properly understood by the administration of government. The persons, therefore, to whose immediate management these different matters are committed ought to be considered as the assistants or deputies of the Chief Magistrate, and on this account they ought to derive their offices from his appointment, at least from his nomination, and ought to be subject to his superintendence. ${ }^{94}$

Establishing agencies independent of presidential control is in tension with this passage, and it therefore might be difficult to justify modern checks and balances doctrine from a literalist reading of the framers' original understanding. ${ }^{95}$

${ }^{82}$ Id at $426-27$.

${ }^{83}$ Id at 427.

24 Federalist 72 at $435-36$ (emphasis added).

${ }^{8 s}$ But see text accompanying notes 205-06 (early practice reveals fracturing of the executive). 
But as I have argued throughout, there is another way of reading the framing materials. All of the framers' discussions of executive power, including the passage above regarding presidential "superintendence," must be understood from the predicate of a strong legislature and a limited executive that did not exercise any legislative powers. This was true when the delegates agreed that although Congress could delegate powers to the executive, such powers had to be "not legislative nor judiciary in their nature." it was true during the ratification period, which was influenced by The Federalist Papers. From a new predicate-where legislative powers are delegated to the executive-a new structure might be well justified.

\section{After the Demise of the Nondelegation Doctrine:}

IMPLementing the Decision of 1787 from a NeW PrEmise

\section{A. Updating the Original Understanding}

Proper regard to originalism requires that we not simply jettison the 1787 understanding in light of twentieth-century developments. But requiring a literal replication of the framers' strong, unitary executive ${ }^{97}$ in the new, post-nondelegation doctrine world distracts from the more significant task of ensuring that in such a world, power is not overly concentrated in one branch of government.

It makes little sense to take a literal originalist approach to the question of congressional control of executive action. As shown in Section II, the framers' conception was not of executive power plain and simple, but rather of the proper amount of executive power to counterbalance what they perceived would be a strong, overreaching, self-aggrandizing Congress. A properly originalist approach would recognize that to be true to the framers, that is, to our constitutional tradition, we must carry over $^{88}$ their basic structural understandings to a time when some of the structural elements have shifted. To maintain other structural elements in stasis results not in a. recapturing of the framers' understanding of checks and balances, but in its alteration.

\footnotetext{
98 Farrand, I Records at 67 (cited in note 56).

${ }^{97}$ See note 14 (listing advocates of the chain of command theory). See also Morrison $v$ Olson, 487 US 654, 697-99 (1988) (Scalia dissenting).

's See the etymology of "metaphor" as "from [the Greek] metapherein, to carry over, transfer." Webster's Third New International Dictionary at 1546 (Merriam-Webster, 1986).
} 
Accordingly, my argument in this Section is that we must evaluate twentieth-century congressional framework legislation in light of the great twentieth-century giveaway of legislative power. If the feared Congress starts giving away its broad-reaching legislative power to the very actor who was thought to provide a check on such power, then for the essential balance of powers to be maintained, the President himself must now be checked.

One must understand the development of congressional control of executive action through this lens. The framers understood as well as we do that the President cannot execute the laws himself. But as the world got more complicated, so did congressional legislation, and therefore so did execution; more laws enacted meant more laws to execute. If execution involved some degree of discretion-as in deciding when to bring a criminal charge-such discretion was an accepted part of the law's enforcement.

So far, the story should offend no one. ${ }^{99}$ But Congress not only passed more laws, requiring more execution; it also passed more laws requiring broad-scale policy making before execution. A law requiring the enforcement of particular rules governing communications, for example, delegates typical executive enforcement discretion, but a law authorizing administrative action in the "public convenience, interest, or necessity" delegates something much closer to pure lawmaking power. ${ }^{100}$ To be sure, the administrator of the latter law would technically be acting as "agent" to the legislative "principal." But when the principal's command merely sets forth a jurisdiction (communications, say) and then provides virtually no further guidance, so long as the agent acts within this jurisdiction, almost any action it takes will not be inconsistent with the principal's "intent." Thus, an executive branch "interpretation" of a law that provides virtually no guidance is best dubbed "lawmaking," or at a minimum "interpretive lawmaking."101

98 Well, almost no one. I omit any discussion here of challenges to an increasing federal regulatory presence based on the Takings Clause, Contracts Clause, Due Process Clause, and Commerce Clause.

${ }_{200}$ See Communications Act of 1934, ch 652, title III, $\S 307,48$ Stat 1083 (June 19, 1934), codified at 47 USC $\S 307$ (1988). Section 307(a) provides that the Federal Communications Commission, "if public convenience, interest, or necessity will be served thereby, subject to the limitations of this chapter, shall grant to any applicant therefor a station license provided for by this chapter."

101 See Martin v Occupational Safety and Health Review Commission, 499 US 144, 151-53 (1991). See also Greene, $1991 \mathrm{~S} \mathrm{Ct}$ Rev at 281-82 (cited in note 4). 
The Court tried only twice to halt such broad delegations ${ }^{102}$ before realizing that it was too difficult to draw a line between delegations that are unconstitutionally broad, because they give the executive something that looks like lawmaking power, and those that are sufficiently narrow, because they grant something that looks like enforcement discretion. The Court's refusal to enforce the nondelegation doctrine seriously-to strike down broad delegations of lawmaking power to the executive-must be seen as the premise for all other checks and balances cases in the post-New Deal era. From the prior premise, executive power was cabined narrowly enough (at least in the domestic sphere) to prevent concern about the balance of power shifting toward the executive. But now that the nondelegation doctrine no longer provides an enforceable rule against excessive delegation, the balance of power tips toward the executive every time Congress delegates lawmaking power.

Much of checks and balances law since the demise of the nondelegation doctrine can be seen as a response to congressional efforts to assure the framers' balance between Congress and the President. ${ }^{103}$ Reacting to presidential power made extraordinary by broad delegations of lawmaking power, Congress has enacted legislation that checks presidential tyranny in three ways. First, Congress has given itself a role in the appointment of officers or in the execution of the laws. Second, it has attempted to legislate outside the Article I, Section 7 process. Third, Congress has sought to check executive-branch tyranny by removing various agencies that exercise executive, legislative, and judicial power from the direct control of the President, and by providing for investigations of intra-executive branch corruption by an officer outside the presidential chain of command.

The first and second efforts properly have been invalidated. ${ }^{104}$ For controlling executive power through the threat of congressional aggrandizement exacerbates rather than solves the concentration of powers problem. Although only the first category concentrates legislative and executive power (in the hands of Congress), the second category also involves Congress's efforts to skew the division of

${ }^{102}$ See Panama Refining Co. v Ryan, 293 US 388, 430 (1935); A.L.A. Schechter Poultry Corp. v United States, 295 US 495, 541-42 (1935).

${ }^{103}$ Nothing here turns on whether rebalancing to ensure a healthy balance of powers was the purpose of any given law; my argument is the same even if the rebalancing was merely an unintended effect of the legislation in question.

${ }_{104}$ But see, for example, Eskridge and Ferejohn, 80 Georgetown L J at 540-43 (cited in note 8), who would permit congressional ex post control as a readjustment of power. 
governmental power in its favor. For when Congress tries to make law outside the constitutionally mandated process, the comparative reduction of presidential power reduces the multiple repositories of power that are so central to the structure of national government. The third category of legislation, on the other hand, avoids the vice of concentrating power in either named branch of government. Here, Congress's efforts properly have been validated, ${ }^{105}$ for they check presidential aggrandizement without the concomitant risk of congressional aggrandizement.

Let me address one obvious problem at the outset. How can independent agencies-which often combine legislative and executive (not to mention adjudicative) functions-not contravene the core tenet against execution by the lawmaker? I have three responses. ${ }^{106}$ First, and most importantly, independent agencies still represent an important curtailment of presidential power. The concentration of lawmaking and executing powers in the President reduces the multiple repositories of power established by the framers; selecting certain jurisdictional areas for independent lawmaking and executing helps ensure that the repositories of power are truly multiple.

Second, judicial review of the action of any agency that combines legislative and executive power might be a constitutionally required check. Such judicial review should pay special attention to the use of these combined powers to help certain narrowly defined groups at the expense of other groups or the public at large. Indeed, one way of understanding the literature supporting an active judicial role in policing interest group politics ${ }^{107}$ is to hearken back to the core suspicion of governmental officials who legislate as well as execute. Judicial review may not eliminate the intermingling of powers problem, but it can ameliorate the problem. This is true for executive agencies as well, though I am not sure that judicial review of executive agency action is a sufficient check. The President commands such an extraordinary combination of lawmaking and executing powers in the post-nondelegation doctrine

${ }^{105}$ See id at 544.

${ }^{108}$ I also agree with Rebecca Brown's descriptive claim that the Court "has never seriously questioned the validity of the commingling of legislative, executive, and judicial functions" in the context of administrative agencies. See Brown, $139 \mathrm{U} \mathrm{Pa} \mathrm{L} \mathrm{Rev} \mathrm{at} 1556$ (cited in note 9).

${ }^{107}$ See, for example, Jonathan R. Macey, Promoting Public-Regarding Legislation Through Statutory Interpretation: An Interest Group Model, 86 Colum L Rev 223 (1986). But see Einer R. Elhauge, Does Interest Group Theory Justify More Intrusive Judicial Review?, 101 Yale L J 31 (1991). 
world that the establishment of independent agencies combined with hands-on judicial review of executive agency action properly counteracts the concentration of power problem.

Third, even with power diffused rather than concentrated in the President, and even with hands-on judicial review, many independent agencies are still deviations from the norm of divided legislative and executive powers. But what else should we expect in a post-nondelegation doctrine world? By enforcing the nondelegation doctrine along with rules against congressional execution, we could ensure against combined legislative/executive powers. But once we permit the nondelegation doctrine to collapse, the chances are great that the body that receives the delegated lawmaking power will also execute the law. This need not be the case, of course; we could insist that delegations of power go to pure rulemaking agencies only, without executive power. One example of such an agency is the United States Sentencing Commission, the constitutionality of which was upheld in Mistretta $v$ United States. ${ }^{108}$ Interestingly, the "pure" rulemaking done by the Sentencing Commission was the lightning rod for Justice Scalia's dissent. ${ }^{109}$ For Scalia, rulemaking by agencies (executive or otherwise) is permissible only if ancillary to execution or adjudication. To maintain the formalism that Congress may not delegate lawmaking power, Scalia would validate agency lawmaking when he can comfortably call it execution or adjudication; for Scalia, "naked" lawmaking-done by a pure rulemaking body-deprives us of the formalist cloak of "ancillarity." But it would make no sense to say that an agency that acts pursuant to a standard such as "public convenience, interest, or necessity," for example, ${ }^{110}$ is "really" just executing. ${ }^{111}$ The statement makes sense only as a formalism, but it is unclear what the virtues of such a formalism are, because we can see through the formalist facade so easily. Scalia's mistake is instructive: in correcting it, we are reminded that Congress does delegate vast amounts of lawmaking power, and we can see the virtues of pure rulemaking bodies, stripped of the temptations that arise from combining lawmaking with executing.

108488 US 361 (1989).

109 Id at $413,416-22$ (Scalia dissenting).

${ }^{110}$ See 47 USC \& 307(a) (1988).

11 Lee Liberman makes the same error as Scalia. See Liberman, 38 Am U L Rev at 323 (cited in note 14). It seems rather unhelpful to say that any exercise of statutory gap-filling by the President is a proper exercise of executive power merely because it is the President who has acted. 
The following is a description of how the Court's twentiethcentury checks and balances doctrine fits together. In many instances, the Court's explanation of its holding does not match the structural constitutional explanation I have just given. In particular, independent agencies have often been defended as enabling politically insulated experts to make "good government" decisions. As I explain below, this argument seems to me without constitutional pedigree. But I am not defending the Court's exegesis of its checks and balances doctrine; I defend only its holdings as both consistent and correct.

1. Congress may not play a role in appointing officers or in executing the laws.

Allowing Congress to play a role in appointing officers or in executing the laws would be an easy way to ensure against excessive presidential power. But when Congress tries to give power to itself $^{112}$ in a way that the Constitution does not clearly authorize-particularly when Congress vests itself with functions best deemed executive- the danger of excessive, concentrated congressional power looms. Without always recognizing this as the central problem, the Court has invalidated a number of laws that, we can now see, improperly aggrandized Congress.

The first case in this category was Myers $v$ United States. ${ }^{113}$ Despite legislation requiring that postmasters "may be removed by the President by and with the advice and consent of the Senate," the President unilaterally fired Myers, a postmaster first class in Portland, Oregon. ${ }^{114}$ In Chief Justice Taft's opinion for the Court, one can find three theories on which the law was invalidated. Two of these theories, focusing on congressional limitation of the presidential chain of command over executive officers, have since been rejected by the Court; the third theory, stressing the senatorial role in the removal of a purely executive officer, retains its vitality today. Thus, although the Court's focus was on Congress's limiting the President's chain of command over executive officers, I suggest that we consider the Myers holding still correct-rather than

112 When I speak of Congress giving "itself" power, I also mean to include giving power to a part of itself, for example, the one-House veto in INS v Chadha, 462 US 919 (1983), or someone it controls, such as the Comptroller General in Bowsher v Synar, 478 US 714 (1986).

113272 US 52 (1926).

114 Id at 107. 
merely a relic-because, and only because, Congress sought to give the Senate a role in removing an executive officer.

The broadest theory, and the one that takes up most of Taft's opinion, is the "chain of command theory":"115 Because there must be a chain of command leading back to the President from all officials exercising executive power, all such officials must be removable at will, either by the President or by an executive officer who is removable at will by the President, and so on. This theory was whittled away in Humphrey's Executor $v$ United States, ${ }^{116}$ and was (perhaps) completely jettisoned in Morrison v Olson. ${ }^{117}$ One must remember, though, that Myers was decided in 1926, before the great giveaway of legislative power to the President required a reconceptualization of appropriate congressional checks on presidential action. In a world in which Congress still held the reins of most legislative power, regulating the President's control of executive officials seemed, correctly, to imbalance powers in favor of Congress. In the later, post-nondelegation doctrine world, the same regulation takes on a different appearance.

Taft based the chain of command theory in part on his reading of the first Congress's treatment of the removal issue. The bill creating the Department of Foreign Affairs had at first provided that the Secretary of Foreign Affairs would be "removable from office by the President of the United States."118 Partly in response to the objection that this language would be construed as a congressional grant of removal power to the President, rather than as a restatement of a presidential power already extant in the Constitution, the bill was amended to eliminate the above-quoted language. ${ }^{119}$ Taft thus concluded that the Constitution's framers, many of whom were in the first Congress, understood that the President would exercise sole removal power over officials carrying out executive functions. But Brandeis's dissent ${ }^{120}$ and subsequent scholarship ${ }^{121}$ have at the very least shown that there are multiple explanations for the amendment. The representatives who voted for the change were a combination of (a) those who thought the President had nonregulable removal power, and (b) those who

115 See note 14.

118295 US 602, 626-27 (1935).

117487 US 654, 686-93 (1988). I discuss both Humphrey's Executor and Morrison below.

${ }^{118}$ Myers, 272 US at 112.

110 Id at 112-14.

${ }^{120}$ See id at 284-85.

${ }^{221}$ See Corwin, 27 Colum L Rev at 361-62 (cited in note 13). 
thought the default rule was that Congress could regulate the President's removal power, but should refrain from doing so in the case of foreign affairs.

To support his chain of command theory, Taft also relied on structural arguments, some of which had been made in the first Congress. Because the President cannot physically execute the laws himself, but must take care that the laws be faithfully executed, he must have power to control the officials who are acting as his agents. ${ }^{122}$ But whatever weight this argument might have carried in a world in which agency officials merely executed the law, it is premised on an inaccurate description of agencies in the post-nondelegation doctrine world. It is one thing to say the President must control those officials who are merely carrying out the law in his stead; it is another to suggest that he must control those officials who are making law in Congress's stead. In fact, once the presidency has become bloated with legislative power, the framers' conception of a balance of power between the executive and legislative branches seems to require not strong presidential control, but a weakening of presidential hegemony.

Taft correctly argued that Congress does not have plenary power over the structure of removals simply by virtue of its power to create or dismantle an agency. ${ }^{123}$ That is, to suggest that the greater power of creating and dismantling carries with it the lesser power of dictating the structure of removals-as Holmes argued in his dissent ${ }^{124}$-is to endorse the possibility of direct congressional control of execution, which would violate the fundamental checks and balances rule against aggrandizement. Taft went further, however, in suggesting that it would be wrong to read the Constitution as granting "to Congress [ ] the function of defining the primary boundaries of another of the three great divisions of government."125 Although this statement makes some sense from the nondelegation doctrine premise, once Congress has given away vast amounts of its own lawmaking power to the executive branch, it has already begun defining the boundaries of another branch, by expanding those boundaries. In the post-nondelegation doctrine world, congressional regulation of executive action represents not a power grab, but a limitation on power given.

${ }^{122}$ See Myers, 272 US at 131-35.

${ }^{123}$ Id at 125-31. Taft made this argument in support of the broadest theory, but in a way also applicable to the narrowest theory (discussed below) as well.

${ }^{124}$ See id at 177 (Holmes dissenting). See also id at 245 (Brandeis dissenting).

125 Id at 127. 
The next broadest theory of presidential power relied on in Myers was what I shall call the "removal tied to appointment" theory: Congress may regulate the removal of an official exercising executive power only if that official is an inferior officer who was appointed by a department head under the second half of the Appointments Clause. ${ }^{126}$ This theory was discarded implicitly in Humphrey's Executor. ${ }^{127}$

Taft based the removal tied to appointment theory in part on evidence that some members of the first Congress viewed removals as incident to the power of appointment. But this argument, in turn, was based on the chain of command theory: "[T] charge of and responsible for administering functions of government who select their executive subordinates need in meeting their responsibility to have the power to remove those whom they appoint."128

The narrowest theory that explains the holding in Myers is what I shall call the "no congressional aggrandizement" theory: Congress may not give itself a role in the removal of officers exercising executive power. It is this theory, focusing on the danger of congressional aggrandizement rather than the danger of congressional regulation of the President, that retains its force today. Although not central to Taft's opinion, this narrowest theory is clearly stated: "[T]he Court never has held . . . that the excepting clause enables Congress to draw to itself, or to either branch of it, the power to remove or the right to participate in the exercise of that power."129 Regardless of whether one is speaking before or after the demise of the nondelegation doctrine, the concern with congressional aggrandizement remains strong. It might be tempting to argue that after ceding vast areas of legislative power to the President, Congress may give itself a role in execution merely to rebalance power. ${ }^{130}$ But rebalancing through reclaiming control in a way not otherwise authorized in the Constitution ${ }^{131}$ poses a

${ }^{126}$ See id at 127, 160-63. See also United States v Perkins, 116 US 483, 485 (1886).

127295 US at $626-27$.

32 Myers, 272 US at 119.

129 Id at 161. See also Taft's holding invalid the Tenure of Office Act, id at 176, which provided for a Senate role in removals, id at $\mathbf{1 6 6 .}$

${ }^{130}$ See INS v Chadha, 462 US 919, 967-74 (1983) (White dissenting); Eskridge and Ferejohn, 80 Georgetown L J at 540-43 (cited in note 8).

${ }^{131}$ See Stephen L. Carter, The Constitutionality of the War Powers Resolution, $70 \mathrm{Va}$ L Rev 101, 112-16 (1984) (arguing that "fresh" checks, where one branch seeks to "rein in" another by applying a power not actually granted to it by the Constitution, upset the balance of power and therefore are unconstitutional). 
threat of legislative tyranny, while merely regulating the President's power does not.

Two years after Myers, in a minor but interesting case called Springer $v$ Philippine Islands, ${ }^{132}$ the Court examined acts of the Philippine Legislature that gave members of the legislature a role in executive actions. Applying the Organic Act of our Congress that constituted the fundamental law of the Philippine Islands, ${ }^{133}$ the Court held that federal checks and balances principles applied to bar the Philippines from giving executive power to its legislature. ${ }^{134}$ Here the nonaggrandizement principle was front and center. For example, the Court wrote, "[l] egislative power, as distinguished from executive power, is the authority to make laws, but not to enforce them or appoint the agents charged with the duty of such enforcement."135

It would be nearly fifty years until the Court again, in Buckley $v$ Valeo, ${ }^{136}$ invalidated a law that improperly granted Congress executive power. The 1974 amendments to the Federal Election Campaign Act of 1971 created a Federal Election Commission with rulemaking, enforcement, and adjudicative powers. ${ }^{137}$ The Act provided that the six voting Commission members would be appointed as follows: two by the President pro tempore of the Senate, two by the Speaker of the House, and two by the President. ${ }^{138}$ In invalidating the appointments provision, the Court reasoned as follows: Because the Commission's members exercise significant authority under federal law, they are "officers" of the United States, who must be appointed pursuant to the Appointments Clause of Article II, Section 2. ${ }^{139}$ But the Appointments. Clause does not authorize Congress to vest in itself the power to appoint officers; this follows from the framers' unwillingness to give Congress executive power (with rare textual exceptions, such as the Senate's check over appointments under the first half of the Appointments Clause). Thus, vesting appointments of officers in the President pro tempore of the Senate and the Speaker of the House

132277 US 189 (1928).

${ }^{133}$ Philippine Organic Act, 39 Stat 545 (1916), made obsolete by Presidential Proclamation No 2695, 3 CFR 64 (Supp 1946) (recognizing Philippine independence).

${ }^{134}$ Springer, 277 US at 201-02.

135 Id at 202.

${ }^{136} 424$ US 1 (1976) (per curiam).

137 See id at 109-13.

${ }^{138}$ See id at 113.

${ }^{139}$ See id at 126, 141. 
was unconstitutional. ${ }^{140}$ Buckley was an easy case:141 Congress had engaged in a blatant act of self-aggrandizement, and the Court struck it down.

Just as Buckley was easy, so was INS $v$ Chadha difficult. ${ }^{142}$ In an effort to recapture control over lawmaking power delegated to the executive, Congress passed many statutes authorizing one or both of its Houses to reject an agency adjudication or rulemaking without presenting this rejection to the President for his signature or veto. In Chadha, the Court invalidated this "legislative veto" on the theory that Congress may not legislate outside the Article I, Section 7 bicameralism and presentment process. ${ }^{143}$

But the facts of Chadha raise serious questions about the majority's analysis. The House, in rejecting the suspension of Chadha's deportation, applied law to fact in an individual case, thus performing what appears to be either an adjudicative or executive act. It is hard to say that such application of law to fact in a particular case constituted lawmaking. Indeed, Justice Powell, concurring in the judgment, observed, "The House did not enact a general rule; rather it made its own determination that [Chadha] did not comply with certain statutory criteria. It thus undertook the type of decision that traditionally has been left to other branches."144 Although Justice Powell characterized the legislative veto in Chadha as improper congressional aggrandizement through adjudication, the similarities between adjudication and execution-both involve application of law to fact in particular cases-permit the conclusion that the legislative veto in Chadha was invalid as congressional execution as well. Thus, although one might question the Court's reasoning, the result in Chadha seems correct.

The proper categorization of action as legislative or executive again reached the Court in Bowsher $v$ Synar. ${ }^{145}$ The Comptroller General is appointed by the President, by and with the advice and consent of the Senate, and is removable by either impeachment or joint resolution (which requires bicameralism and presentment) for limited reasons: "(i) permanent disability, (ii) inefficiency, (iii) neglect of duty, (iv) malfeasance, or (v) a felony or conduct involving

$240 \mathrm{Id}$ at 135.

${ }^{141}$ On the Appointments Clause issue, that is; it was a hard case on the First Amendment issues regarding the regulation of campaign financing.

${ }_{142} 462$ US 919 (1983).

14 Id at 951-59.

144 Id at 964-65.

145 478 US 714 (1986). 
moral turpitude."146 In 1985, Congress enacted the Gramm-Rudman-Hollings Act to eliminate the federal budget deficit. ${ }^{147}$ The Act required the Office of Management and Budget ("OMB") and the Congressional Budget Office ("CBO") to report deficit estimates and budget reduction calculations to the Comptroller General. ${ }^{148}$ It then required the Comptroller General to direct the President to issue a sequestration order mandating certain budget cuts. ${ }^{149}$ Although the Act required that the Comptroller General give due regard to OMB's and CBO's estimates and reductions, "the Act plainly contemplate[d] that the Comptroller General [would] exercise his independent judgment and evaluation with respect to those estimates."150

The majority invalidated what it deemed to be executive powers vested in the Comptroller General by the Act, holding it unconstitutional for Congress to maintain control-through removal-of an officer exercising executive power. The Court explained, the "Constitution does not contemplate an active role for Congress in the supervision of officers charged with the execution of the laws it enacts." In1 In describing the Myers holding, the Court paid no attention to Taft's chain of command theory. Instead it claimed that the Court had held the Myers statute unconstitutional "on the ground that for Congress to "draw to itself, or to either branch of it, the power to remove or the right to participate in the exercise of that power ... would be . . . to infringe the constitutional principle of the separation of governmental powers.' "152 In sum, the Court concluded, the "structure of the Constitution does not permit Congress to execute the laws; it follows that Congress cannot grant to an officer under its control what it does not possess."183

In this way, Bowsher helped strengthen the "no congressional aggrandizement" theory that originated in Myers. The majority's descriptions of the nature of congressional control of the Comptroller General and of the Comptroller General's powers under the Act are not without doubt. I shall describe below Justice Stevens's concurrence in the judgment, which agrees that Congress controls

${ }^{148}$ Id at 728, quoting 31 USC $\S 703(e)(1)(B)$.

${ }_{147}$ Balanced Budget and Emergency Deficit Control Act of 1985, Pub L No 99-177, 99 Stat 1038, codified at 2 USC $\S 901$ (1988).

14899 Stat at 1063-68.

140 Id at 1072-78.

1so Bowsher, 478 US at 732.

${ }^{181}$ Id at 722 .

${ }^{182}$ Id at 724, quoting Myers, 272 US at 161.

${ }^{183} 478$ US at 726. 
the Comptroller General, and that Congress had improperly aggrandized its own powers, but for reasons different from those of the majority. Importantly, though, seven Justices agreed that by seeking to exert ex post control over the Comptroller General, Congress had improperly aggrandized its powers.

2. Congress may not make law outside the finely wrought Article I, Section 7 bicameralism and presentment process.

Congressional attempts to evade the requirements of Article I, Section 7 bicameralism and presentment also represent a grab for power outside clear constitutional lines. ${ }^{\mathbf{1 5 4}}$ The problem here is somewhat different from the problem in the previous category of cases. ${ }^{155}$ Here, rather than trying to do someone else's job (execute the law), Congress tries to do its own job (legislate), but without the strictures of bicameralism and presentment. By excluding the President from the lawmaking process, Congress threatened, in these cases, to concentrate power in its own hands in a potentially dangerous manner.

The key case in this second category is INS $v$ Chadha, ${ }^{\mathbf{1 6 8}}$ in which, as described above, the Court invalidated the legislative veto. Chadha's deportation by the House of Representatives is probably best characterized as executive action (or judicial action, per Justice Powell). But soon afterward the Court summarily applied Chadha to legislative vetoes of rulemakings, clearly legislative action. ${ }^{157}$ The theory behind the invalidation is that although Congress may delegate legislative power to administrative agencies, it may not delegate such power back to itself. Agencies are checked by judicial review, but Congress using the legislative veto is not. For Congress to reserve the power to legislate without a check either from the President's veto or by a court's review, is to aggrandize power-to collapse into Congress's hands power meant to be exercised by more branches than one. ${ }^{158}$

184 What results from these efforts are not, of course, "laws" in the Article I, Section 7 sense. I shall, however, refer to congressional efforts at controlling lawmaking outside Article I, Section 7 as congressional efforts to make "law" outside Article I, Section 7, because Congress's goals are the same in such situations as when it formally passes "laws."

${ }^{155}$ See text accompanying notes 103-05.

156 462 US 919 (1983).

${ }^{137}$ Process Gas Consumer Group v Consumers Energy Council of America, 463 US 1216 (1983), summarily affirming 673 F2d 425 (DC Cir 1982); United States Senate v FTC, 463 US 1216 (1983), summarily affirming 691 F2d 575 (DC Cir 1982).

${ }^{158}$ But see Section IV. This justification for extending Chadha to the rulemaking setting raises an intriguing question. If Congress were to amend the Administrative Procedure 
In Bowsher, Justice Stevens, concurring in the result, applied this reasoning from Chadha to the Gramm-Rudman-Hollings Act. As described above, the Court invalidated the Act on the ground that it vested an officer controlled by Congress with executive power. Justice Stevens disagreed with the majority regarding the way in which Congress controls the Comptroller General and the nature of the Comptroller General's power. Tellingly, though, he agreed with the majority's conclusion that Congress had improperly aggrandized itself.

For Stevens, reservation of congressional power to remove the Comptroller General by joint resolution for "permanent disability, inefficiency, neglect of duty, malfeasance, or a felony or conduct involving moral turpitude"159 constituted not authorization to remove "for any number of actual or perceived transgressions of the legislative will," "160 but rather a severe restriction on removal, rendering the officer virtually "independent."161 Indeed, in Humphrey's Executor v United States, ${ }^{\mathbf{1 2} 2}$ the Court had construed similar removal language as creating a relatively independent, rather than dependent, agency. ${ }^{163}$ Despite differing with the majority over the importance of Congress's removal power, Stevens nonetheless shared the majority's conclusion that "the Comptroller General is properly characterized as an agent of Congress," by virtue of the other statutory responsibilities the Comptroller General owes to Congress. ${ }^{164}$

So the Bowsher majority and Justice Stevens agreed (though for different reasons) that Congress controlled the Comptroller General. The question then became: Is the Comptroller General merely a congressional employee performing functions in aid of Article I, Section 7 legislation, ${ }^{165}$ or is he performing executive or legislative functions himself? As mentioned above, the majority concluded that interpreting and implementing the governing statute

Act to permit its legislative vetoes to be reviewed by a court under $\S 706$ 's various review provisions, should the reviewable legislative veto (in the rulemaking setting) stand as constitutional? By providing the same check over its action as exists over an agency's action, arguably Congress has not aggrandized itself, and arguably this hypothetical law should be upheld.

${ }^{169}$ Bowsher, 478 US at 728, quoting 31 USC $\S 702(\mathrm{e})(1)(B)$.

160 Id at 729 (majority opinion).

161 Id at 739 (Stevens concurring).

162295 US 602 (1935).

${ }^{183}$ See text accompanying notes $185-89$.

${ }^{164}$ Bowsher, 478 US at 746.

168 Congress can "control" its aides through both appointment and removal. See Buckley $v$ Valeo, 424 US 1, 137-39 (1976). 
"is the very essence of 'execution' of the law."168 Thus, Congress had improperly maintained control over the execution of the laws. Stevens thought it best to characterize the Comptroller General's rather heady task of telling the President what funds to cut as "the duty to make policy decisions that have the force of law."167 Stevens acknowledged that "Congress could delegate the performance of those functions to another branch of the Government."168 In Chadha, however, the Court had prevented Congress from delegating such power back to a subset of itself, that is, to control policy making outside the Article I, Section 7 process. Thus, the "central question" for Stevens was, "[i]f the delegation to a stranger is permissible, why may not Congress delegate the same responsibilities to one of its own agents?"169

The answer, given implicitly in Chadha and expounded on by Stevens in Bowsher, is that

[i]f Congress were free to delegate its policymaking authority to one of its components, or to one of its agents, it would be able to evade the carefully crafted restraints spelled out in the Constitution. That danger-congressional action that evades constitutional restraints-is not present when Congress delegates lawmaking power to the executive or to an independent agency. ${ }^{170}$

As I have explained above, the problem is one of congressional aggrandizement-Congress making law without the check of the presidential veto or judicial review. It is hard to tell whether the majority or Stevens better characterized the Comptroller General's power under the challenged Act. Implementing congressional legislation through interpretation that leaves room for administrative judgment and discretion is both executive and legislative in quality. In fact, such actions are best deemed "interpretive lawmaking." 171 But how we resolve the categorization dispute is actually irrelevant. Even if we acknowledge that the Comptroller General's powers under the Act are a little bit executive and a little bit legislative, in either case Congress has improperly tried to aggrandize itself, either by controlling the execution of the laws or by control-

\footnotetext{
${ }^{188}$ Bowsher, 478 US at 733.

187 Id at 754.

${ }^{168}$ Id at 753.

169 Id.

170 Id at 755 (citations omitted).

171 See text accompanying note 101.
} 
ling legislation through non-Article I, Section 7 means. So both the majority and Stevens were right.

As if in response to the above argument about the best way to understand Bowsher, Justice Stevens, now writing for the majority in Metropolitan Washington Airports Authority $v$ Citizens for the Abatement of Aircraft Noise, Inc., ${ }^{172}$ simply refused to decide whether the power in question was executive or legislative. Here are the facts: Congress ceded management of National and Dulles Airports to the Commonwealth of Virginia and the District of Columbia, which in turn established a regional authority governed by an eleven-member Board of Directors. To allay concern that surrender of federal control of the airports might result in the transfer of much air traffic from National to Dulles, which is quite a bit farther from D.C. than is National, Congress provided (as a condition for transferring power to the regional authority) for a Review Board that required Members of Congress to serve in their individual capacities as representatives of airport users. ${ }^{173}$

The Act specified 'that the Board of Review 'shall consist' of nine Members of the Congress, eight of whom serve on committees with jurisdiction over transportation issues and none of whom may be a Member from Maryland, Virginia, or the District of Columbia."174 The Act detailed "the actions that must be submitted to the Board of Review for approval, which include[d] adoption of a budget, authorization of bonds, promulgation of regulations, endorsement of a master plan, and appointment of the chief executive officer of the Authority."175 The Act further explained that "disapproval by the Board [would] prevent submitted actions from taking effect." ${ }^{178}$ The United States entered into a long-term lease with the regional authority, which agreed to comply with all conditions specified in the Act; thus, the authority established the Review Board, and the Directors appointed the Board's nine members from lists submitted by the Speaker of the House of Representatives and the President pro tempore of the Senate. ${ }^{177}$

One might ask in response to this law: How many ways can one Act violate the Constitution? Avoiding the obvious Appoint-

\footnotetext{
172111 S Ct 2298 (1991).

${ }^{173}$ Id at 2302-03.

174 Id at 2303.

178 Id.

176 Id at 2303-04.

177 Id at 2304.
} 
ments Clause and Incompatibility Clause issues, ${ }^{178}$ the Court first determined that federal checks and balances concerns were implicated because the Review Board exercised federal power and acted as a congressional agent:

We [ ] confront an entity created at the initiative of Congress, the powers of which Congress has delineated, the purpose of which is to protect an acknowledged federal interest, and membership in which is restricted to congressional officials. Such an entity necessarily exercises sufficient federal power as an agent of Congress to mandate separation-of-powers scrutiny. Any other conclusion would permit Congress to evade the carefully crafted constraints of the Constitution, simply by delegating primary responsibility for execution of national policy to the States, subject to the veto power of Members of Congress acting "in their individual capacities."179

Unlike Bowsher, where the majority and Justice Stevens engaged in an extensive categorization battle over whether the Comptroller General's powers were executive or legislative, only to agree in the end that congressional control of the Comptroller General invalidated the statute regardless of the proper labeling of his powers, in Airports, Justice Stevens, now writing for the Court, deemed it unnecessary to determine whether the Review Board's powers were executive or legislative. "If the power is executive, the Constitution does not permit an agent of Congress to exercise it. If the power is legislative, Congress must exercise it in conformity with the bicameralism and presentment requirements of Art. I, $\S 7 . " 180$

The Court in Airports might finally have realized that there is no neutral principle to determine whether fleshing out a congressional directive by an officer of the United States constitutes "executive" or "legislative" action. The action is executive in that it

${ }^{178}$ Id at 2312 n 23. The Appointments Clause and Incompatibility Clause arguments would have gone as follows: An officer of the United States is one who "exercis[es] significant authority pursuant to the laws of the United States . . .." Buckley $v$ Valeo, 424 US 1, 126 (1976). Given the Court's conclusion that the Review Board exercises federal power (see discussion in text below), the Review Board members are officers of the United States. Officers of the United States can be appointed by authorities mentioned in Article II, Section 2 only; the state Board of Directors required by the Act to appoint the Review Board does not qualify as one of these authorities. Even more straightforwardly, the Incompatibility Clause provides: "[N]o Person holding any Office under the United States, shall be a Member of either House during his Continuance in Office." US Const, Art I, § 6, cl 2.

${ }_{170} 111 \mathrm{~S} \mathrm{Ct}$ at 2308 (citation omitted).

180 Id at 2312. 
requires interpretive specification of law; the action is legislative in that such "interpretation" often involves the laying down of general rules in a manner relatively unguided by legislative direction. ${ }^{181}$ Thus, in Martin v Occupational Safety and Health Review Commission, the Court invented the term "interpretive lawmaking" to describe the executive/legislative function performed by agencies. ${ }^{182}$ Justice Stevens's opinion in Airports implicitly recognizes that when Congress seeks either to control the execution of the laws or to legislate through non-Article I, Section 7 means, it aggrandizes itself unconstitutionally. Thus, the Bowsher categorization battle need not be fought. ${ }^{183}$

${ }^{181}$ See Chevron, U.S.A., Inc. v Natural Resources Defense Council, Inc., 467 US 837, 842-45 \& n 9, 865-66 (1984); Greene, $1991 \mathrm{~S}$ Ct Rev at 274-82 (cited in note 4).

182499 US 144, 151 (1991).

183 Understanding Airports in this fashion helps to show how another structural categorization battle was just as unnecessary as the one in Bowsher. The case is Freytag $v$ Commissioner of Internal Revenue, 111 S Ct 2631 (1991). Congress gave the Chief Judge of the Tax Court authority to appoint lower Tax Court judges. The question was whether the Tax Court was either a Court of Law or a Department, so that Congress could properly vest appointment power in the Chief Judge under the second half of the Appointments Clause. US Const; Art II, § 2, cl 2. Justice Blackmun, writing for a five-Justice majority, held that the Tax Court-whose judges adjudicate federal questions, do not have the protections of Article III, but are not removable at will by the President-is a Court of Law. 111 S Ct at 2644-45. Writing for the other four Justices, Justice Scalia would have held the Tax Court to be a Department. Id at 2657-61 (Scalia concurring in the judgment).

The extensive categorization battle between Justices Blackmun and Scalia could have been avoided. In a world in which all federal adjudicators deciding federal questions must be Article III judges, the Tax Court would be unconstitutional. And in a world in which all federal officials exercising some power that could be considered executive must be removable at will by the President, the Tax Court would be unconstitutional. But we do not live in either world. The Supreme Court has upheld so-called "Article I" courts, see Crowell $v$ Benson, 285 US 22, 50 (1932); Thomas v Union Carbide Agricultural Products Co., 473 US 568, 585-89 (1985); Commodity Futures Trading Commission v Schor, 478 US 833, 851 (1986); and has upheld independent agencies, Humphrey's Executor v United States, 295 US 602, 629 (1935); Wiener v United States, 357 US 349, 355-56 (1958); Morrison v Olson, 487 US 654, 696-97 (1988). See also Section III.A.3. So, although in 1787 the Tax Court, as currently structured, would probably have been neither a Court of Law (because not an Article III court) nor a Department (because not under presidential control), today we should consider the Tax Court both a Court of Law (because we have validated Article I courts) and a Department (because we have validated independent agencies). Thus, whereas in Airports the law was unconstitutional because of congressional aggrandizement, regardless of whether one categorized the Review Board's functions as legislative or executive, in Freytag the statute should have been held constitutional because one can categorize the relevant agency, in post-New Deal terms, as a Court of Law or a Department, and because there is no congressional aggrandizement. 
3. Congress may try to hem in executive action not by reaching for power itself, but by regulating the executive's power.

It is undisputed that Congress may curtail executive action by limiting agency funding, personnel, or jurisdiction. Rather, the principal dispute has been over whether Congress can regulate the removal of agency personnel, to ensure that the President does not control all the power delegated away from Congress. In this third category of cases, ${ }^{184}$ the Court has consistently answered yes.

Initially, the Court was quite resistant to the notion of any congressional limitation on the President's power to execute the laws. As described above, the broad chain of command theory announced in Myers required all executive functions to be exercised by an official removable by the President or by an official who in turn is removable by the President (and so on down the chain of command). But nine years later, in the midst of the New Deal, a unanimous Court in Humphrey's Executor v United States ${ }^{185}$ backed away from the chain of command theory, at least at its broadest reach. The Federal Trade Commission (FTC) is empowered to prevent unfair methods of competition in commerce through investigation, reporting, enforcement, and adjudication. The Commission is headed by five commissioners appointed for defined terms of years and removable by the President for limited reasons: "inefficiency, neglect of duty, or malfeasance in office."186 As the Court properly recognized, Congress intended "to create a body of experts who shall gain experience by length of service-a body which shall be independent of executive authority, except in its selection, and free to exercise its judgment without the leave or hindrance of any other official or any department of the government."187 The Court acknowledged that the broad Myers view would require invalidation of the removal restriction, but limited Myers to its facts, holding that "the necessary reach of the deci-

\footnotetext{
184 See text accompanying notes 103-05.

18s 295 US 602 (1935).

186 Id at $619-20$.

${ }^{187}$ Id at 625-26. It is fairly clear that the Humphrey's Executor Court construed the removal language to prevent removal for policy disagreement. See, for example, Shane, 57 Geo Wash L Rev at 608-09 (cited in note 16) ("[I]t is conventionally understood that it would not be cause for removal that such an administrator declined to follow the President's policy preferences in favor of policy initiatives that the administrator prefers and which are also within the administrator's lawful discretion."). But see Lessig and Sunstein, 94 Colum L Rev 1 (cited in note 16). Thus, it appears that Justice Stevens got the better of Chief Justice Burger in characterizing the similar removal language in Bowsher. See text accompanying notes 159-64.
} 
sion goes far enough to include all purely executive officers. It goes no farther ...."188

Humphrey's Executor validated the congressional limitation on presidential removal power in the following fashion: The FTC performs quasi-legislative and quasi-judicial functions. Its executive functions are ancillary to those other functions. Congress created the FTC (and other "independent" agencies) precisely to carry out quasi-legislative and quasi-judicial functions without direct control from political actors (either the President or Congress). ${ }^{189}$ To hold that the President's executive power vests him with nonregulable at-will removal control over all officers exercising any executive tasks would expand the powers of the President beyond those that are merely executive to cover quasi-legislative and quasi-judicial functions as well.

The opinion is problematic. To some extent, it seems to rest on the view that Article I empowers Congress to insulate certain federal decisions from direct political control simply because it deems those decisions best made by nonpolitical "experts." It is not clear to me where this conclusion comes from as a matter of constitutional law. Furthermore, the opinion is muddle-headed in its characterization of the FTC's powers as quasi-legislative and quasi-judicial and as executive only in an ancillary manner. In fact, just like the other agencies that Congress has rendered independent from the President, ${ }^{190}$ the FTC's powers are legislative, executive, and judicial, with no "quasi-" or "ancillary" classifications needed, and no ancillarity about the executive function.

But despite the opinion's flaws, it contains a strong structural justification. The Court explained:

The fundamental necessity of maintaining each of the three general departments of government entirely free from the control or coercive influence, direct or indirect, of either of the others, has often been stressed and is hardly open to serious question. . . . The sound application of a principle that makes one master in his own house precludes him from imposing his control in the house of another who is master there. ${ }^{191}$

${ }^{188}$ Humphrey's Executor, 295 US at 627-28.

189 See id at 628-32.

190 Most federal agencies_-"independent" or "executive"-exercise a hybrid of legislative, executive, and judicial functions.

192295 US at 629-30. 
This is the third justification-the narrow, nonaggrandizement theory-for the outcome in Myers. What the Humphrey's Executor Court recognized, albeit dimly-without fleshing out the contours or firmly grounding the constitutional predicate-is that in the modern administrative state, executing the laws requires more than mere execution: agencies must frequently interpret statutory provisions giving them discretion great enough to render their interpretation "lawmaking." This is nothing less than the alienation of legislative power from Congress to the agencies. Similarly, many modern statutes alienate judicial power from the Article III courts to the agencies. Were Congress constitutionally disempowered from insulating these agency officials from at-will presidential removal, it would lose a valuable tool to ensure against the balance of power tipping too far in the direction of the President.

Combining all lawmaking and execution (not to mention adjudication) in one branch violates the fundamental structural tenets of our federal system: the rule against the tyranny of one branch, the rule against aggrandizement, the rule ensuring multiple repositories of power. But if we accept the new premise that acknowledges that the executive will have lawmaking power (and judicial power too), then it is appropriate to validate new structures that regulate the President to ensure against the corruption of such power, against the risk of self-dealing, self-judging, and self-exemption-in short, against the risk of tyranny. Independent agencies are constitutional precisely because, without aggrandizing Congress, they prevent presidential aggrandizement.

The Court reiterated the Humphrey's Executor holding in Wiener $v$ United States. ${ }^{192}$ Congress had established the War Claims Commission ("WCC") to adjudicate claims for World War II compensation. The law "made no provision for the removal" of the three commissioners. ${ }^{193}$ Instead, "Congress provided for a tenure defined by the relatively short period of time during which the War Claims Commission was to operate." ${ }^{194}$ President Eisenhower decided to replace Commissioner Wiener with one of his own appointees, and fired Wiener when he refused to resign. In another unanimous opinion, the Court held that the WCC's tasks were intrinsically judicial, and therefore that Congress wanted the WCC to operate free from presidential interference. ${ }^{195}$ Again, I am uncer-

\footnotetext{
192357 US 349 (1958).

198 Id at 350 .

194 Id at 352.

198 Id at 355-56.
} 
tain of the constitutional pedigree of the blanket assertion that Congress can insulate delegated legislative or judicial decisionmaking from the President merely because it deems such decisions better made by apolitical actors. But structurally, Wiener has the same virtue as Humphrey's Executor: the law can be seen as providing a check against presidential aggrandizement, as ensuring that if legislative or judicial power is to be alienated from Congress or the federal courts, such power will not simply be gobbled up by the President. ${ }^{196}$

Finally, we have Morrison v Olson. ${ }^{197}$ In response to President Nixon's manipulation of Department of Justice investigations of intra-executive branch corruption, Congress enacted the Ethics in Government Act. ${ }^{198}$ The Act requires the Attorney General to ask a special Article III court (the Special Division) to appoint an Independent Counsel to investigate certain executive branch officials whom the Attorney General has reason to believe have committed federal crimes. The Attorney General's decision whether to request such an appointment is nonreviewable. If appointed, the Independent Counsel has full Department of Justice power to investigate and prosecute within her defined jurisdiction. Although the Special Division may remove the Independent Counsel if it finds that she has completed her assigned tasks, the President (through the Attorney General) may remove the Independent Counsel only "for good cause, physical disability, mental incapacity, or any other condition that substantially impairs the performance of such independent counsel's duties."199

Thus, the Ethics in Government Act represents a congressional attempt to limit the President's control over purely execu-

${ }^{196}$ Some scholars have agreed that insulating agency adjudication from presidential control is legitimate, but that insulating agency policy making from presidential control is not. See, for example, Bruff, 88 Yale L J at 498-99 (cited in note 9); Gifford, 55 Geo Wash L Rev at 463-69 (cited in note 9); Pierce, 64 Tex L Rev at 511 (cited in note 14); Strauss, 84 Colum L Rev at 609-16 (cited in note 14). But this support for insulating adjudicative offcials from presidential control really deprives the President of nothing, for those officials are sapping Article III courts of power, not the President. Of course it is permissible to insulate adjudicative officials from political power. The question is not whether their insulation from the President is constitutional, but whether it is constitutional to fail to use Article III methods (life tenure and salary protection) in doing so. See Crowell $v$ Benson, 285 US 22 (1932); Northern Pipeline Construction Co. v Marathon Pipe Line Co., 458 US 50 (1982); Thomas v Union Carbide Agricultural Products Co., 473 US 568 (1985); Commodity Futures Trading Commission v Schor, 478 US 833 (1986).

197487 US 654 (1988).

${ }^{108}$ Pub L No 95-521, title VI, § 601(a), 92 Stat 1867 (1978), codified at 28 USC § 596 (1988).

${ }^{199}$ Morrison, 487 US at 663, quoting 28 USC $\S 596(a)(1)$. 
tive officers by vesting appointment in the Special Division and by limiting presidential removal to good cause. Both the appointments and removals questions turned on whether Congress may constitutionally disrupt the chain of command over a purely executive officer. Acknowledging that Humphrey's Executor seemed to say that purely executive officers may not be insulated from presidential control, the Morrison Court further eroded the chain of command theory:

[O]ur present considered view is that the determination of whether the Constitution allows Congress to impose a "good cause"-type restriction on the President's power to remove an official cannot turn on whether or not that official is classified as "purely executive." . . . [T] he real question is whether the removal restrictions are of such a nature that they impede the President's ability to perform his constitutional duty $\ldots . .^{200}$

Unfortunately, the Court could do no better than this formulation in explaining the constitutional legitimacy of the Independent Counsel. As Justice Scalia's scathing dissent shows, the Court's language is based on no theory of checks and balances, but merely on an ad hoc judgment that the deprivation of presidential power here is not too great. ${ }^{201}$ Although one could provide a policy justification for the Independent Counsel-and, indeed, for many independent agencies-by arguing that officers insulated from political checks can sometimes make "better" decisions than those subject to political control, this argument has no structural constitutional pedigree. Insulation of executive officials from presidential control is justifiable if done to prevent the President himself from growing too powerful, not if done simply to avoid the constraints of politics.

Furthermore, just as the "better decision making" argument cannot save Morrison, neither can we justify the Ethics in Government Act as we did the hybrid independent agencies. Recall that the hybrid independent agencies are justified on the ground that they make law as well as execute it, and therefore it is appropriate to limit presidential control to avoid placing too much lawmaking power in the executive. ${ }^{202}$ The Independent Counsel, however, exercises no legislative functions, only executive.

200487 US at 689,691 .

201 Id at 711-712 (Scalia dissenting).

202 Another reason to insulate hybrid agencies from the President's complete control is that they perform judicial functions as well. 
There is, though, a justification for the Morrison result that is perfectly consonant with the original balance of powers theme, with the framers' concern with corruption and self-dealing within any branch of government. The Ethics in Government Act can be seen as intruding into executive power precisely when executive power fails to operate-when the executive has, in effect, exempted itself from the execution of the laws. The Independent Counsel thus can be seen as a check not over the execution of the laws, but over the failed execution of the laws. This justification for Morrison advances the framers' core value of preventing self-dealing and self-exemptions, so clearly the theme of Federalist 10 and $78 .^{203}$ On this reading of Morrison, the Court would invalidate many restrictions on presidential control of purely executive officers, unless the restriction were needed to prevent presidential self-dealing.

$$
* * * * *
$$

Let me summarize the conclusions of this Section: Much of post-New Deal checks and balances doctrine makes sense if we (a) recall that the framers' core checks and balances value was to ensure a balance of power among the branches-to prevent the tyranny of any one branch (and thus help preserve individual liberty), to avoid placing legislative and executive power in the same branch of government-and (b) start from a premise in which broad delegations of lawmaking power from Congress to the President are accepted as constitutional. Thus, we can (c) approve congressional attempts to regulate presidential action where such action would otherwise enlarge presidential power beyond execution or would involve executive branch self-dealing, but (d) invalidate congressional attempts to control execution itself or to make law outside the Article I, Section 7 process, because such aggrandizement concentrates power back in the hands of Congress. In this way, the Court's checks and balances jurisprudence can be rendered both internally consistent and consistent with the framers' understanding of the balance of power in the federal government. In a new world in which Congress gives away legislative power, additional congressional efforts to control the now-enlarged executive are faithful to, rather than in tension with, the Constitution of 1787.

The twentieth-century checks and balances doctrine, which is often unjustly criticized as shifting inconsistently between formalism and functionalism, ${ }^{204}$ is thus rendered coherent. To be sure, the Court's explanations for its holdings have changed and often

${ }^{203}$ See Federalist 10 (Madison), in Federalist Papers at 77, 80-81 (cited in note 23); Federalist 78 (Hamilton) at $464,467$.

${ }^{204}$ See note 9. 
have evidenced an ad hoc quality when clearer principles would have been welcome. But the holdings in these cases are quite consistent; the resulting doctrine, although no doubt in need of elaboration, makes a great deal of sense, both in terms of internal coherence and as measured by constitutional values. The Court permits Congress to regulate executive branch lawmaking or self-dealing so long as Congress does not expand its own powers in so doing and thus threaten the return of congressional aggrandizement. The Court's doctrine thus comports with the legitimate translation of the framers' Constitution outlined above.

This is not to say that all is well with the allocation of power between the President and Congress, as monitored by the Court. The presidential veto has become, in certain narrowly defined circumstances, a method of entrenching presidential lawmaking rather than simply blocking congressional initiative. I address this in Section IV.

\section{B. The Comparative Irrelevance of Accountability}

One result of these developments-an underenforced nondelegation doctrine, independent agencies, and a rule against Congress giving itself control over execution or lawmaking outside Article I, Section 7-is that national policy is sometimes made by neither of the elected actors (Congress or the President), but rather by unelected "independent" agencies. This seems to violate a basic constitutional value. But as I have shown in Section II, the framers' discussions of a "unitary" executive, though sometimes mentioning "responsibility," were focused primarily on the need for balance, for nonagglomeration. In fact, the principle behind our checks and balances structure is in tension with the norm of accountability. The framers knew they could have ensured an energetic, efficient government by vesting lawmaking and executing powers in one person, or by creating a unicameral legislature with no presidential veto. Accountability would be quite clear in such a structure-the citizens would know precisely whom to blame. But the framers were more concerned with making the machinery of government somewhat cumbersome, thus ensuring against the hegemony of one branch or person. By dividing powers and insisting upon a complex system of checks-bicameralism, presentment, and judicial review (not to mention federalism) - the framers ensured against such hegemony, but simultaneously sacrificed accountability. It is pretty hard for citizens to know precisely whom to blame when something goes wrong in such a system. 
Another argument against deeming accountability the core checks and balances concern is that in the late eighteenth and early nineteenth centuries, Congress established various offices that were not controlled in any centralized fashion by the President-such as the Department of the Treasury, the Post Office, and the United States Attorneys. ${ }^{206}$ This early practice is relevant in locating the proper place of presidential accountability for checks and balances analysis, because it shows that a strong norm of centralized authority was not present shortly after the framing. ${ }^{206}$

Furthermore, independent agencies are not totally unaccountable. ${ }^{207}$ Although the President may not remove the heads of such agencies for policy disagreements, he does control (with the Senate) appointment and reappointment; he may often select the chairperson of the agency; the agency might depend on the President for information and for support during budgetary negotiations with Congress; the agency's budget probably goes through the Office of Management and Budget for review; and most agencies must work through the Department of Justice with regard to litigation. Furthermore, citizens can still hold both Congress and the President accountable for appointments to the independent agencies, and for the legislative delegations to those agencies. Therefore, there is enough accountability to prevent the independent

${ }^{205}$ See, for example, Gerhard Casper, An Essay in Separation of Powers: Some Early Versions and Practices, $30 \mathrm{Wm} \&$ Mary L Rev 211, 240-42 (1989); Nathan D. Grundstein, Presidential Power, Administration and Administrative Law, 18 Geo Wash L Rev 285, 299 (1950); Harold J. Krent, Executive Control Over Criminal Law Enforcement: Some Lessons From History, 38 Am U L Rev 275, 281 (1989); Lessig and Sunstein, 94 Colum L Rev 1 (cited in note 16); Shane, 57 Geo Wash L Rev at 603-06, 615-17 (cited in note 16); Charles Tiefer, The Constitutionality of Independent Officers as Checks on Abuses of Executive Power, 63 BU L Rev 59, 70-76 (1983).

${ }^{208}$ Lawrence Lessig and Cass Sunstein show that early practice reveals a fragmented executive, but argue nonetheless that concerns with accountability and coordination render the modern independent agency unconstitutional in many circumstances. Lessig and Sunstein, 94 Colum L Rev 1 (cited in note 16). There are two central problems with Lessig and Sunstein's thesis. First, the evidence they marshal so well to show an early practice of diffusion makes it difficult to understand the source of the constitutional norm of strong accountability and coordination. That evidence shows that the framers in Congress in the late eighteenth and early nineteenth centuries had a much more relaxed view of presidential accountability and coordination than Lessig and Sunstein have. Second, Lessig and Sunstein fail to deal with the problem of concentrating executive and legislative power in the President's hands.

${ }^{207}$ See Bruff, $36 \mathrm{Am} \mathrm{U} \mathrm{L} \mathrm{Rev} \mathrm{at} 507$ (cited in note 9); Oliver A. Houck, President $X$ and the New (Approved) Decisionmaking, 36 Am U L Rev 535, 550 (1987); Miller, 1986 S Ct Rev at 43 (cited in note 9); Alan B. Morrison, How Independent Are Independent Regulatory Agencies?, 1988 Duke L J 252, 252-54; Pierce, 64 Tex L Rev at 511-13 (cited in note 14); Strauss, 84 Colum L Rev at 587-95 (cited in note 14). 
agencies from being truly free-floating. The remaining degree of insulation from at-will presidential removal enables some degree of policy independence, thus helping to ameliorate the concentration of power problem. Given the framers' focus on ensuring against the concentration of legislative and executive power in either political branch, and given the implicit concession, through the establishment of our cumbersome system of checks, that accountability could be sacrificed in the name of dividing power, the independent agencies on balance help preserve the framers' values.

Thinking of checks and balances doctrine as a package also shows that there is more than one way to preserve the framers' values; independent agencies are not the only solution. One intriguing alternative the Court appears never to have considered is this: If the Court were to invalidate independent agencies and validate the legislative veto, it could both limit presidential power (through the legislative veto) and assure strong accountability (through both presidential control over agencies and through congressional ex post control over agencies via the legislative veto). ${ }^{208}$ Rather than depriving both named branches of control, this inversion of current doctrine would assure both branches of control.

I shall not attempt a complete analysis of the virtues and vices of such an inversion; suffice it to say that there is an obvious risk of congressional aggrandizement through such an assertion of ex post, operational-level control. However, if Congress would subject itself to Administrative Procedure Act judicial review-that is, treat itself as an agency when it engages in legislative vetoes-the Article III branch check over Congress might be enough to ensure against congressional aggrandizement. Ultimately, even if this alternative would be less desirable than the current regime, which validates independent agencies and invalidates the legislative veto, thinking in this manner-considering checks and balances doctrine as a package, rather than as a list of separate decisions-is the only way to ensure fidelity to the underlying principles of balance of powers and of disaggregating legislative from executive power.

\section{Checking the "Entrenching" Presidential Veto}

Although the post-New Deal Court has been faithful to the framers' principle of balance by permitting independent agencies while forbidding congressional aggrandizement, it has not yet re-

${ }^{208}$ A legislative veto in an adjudicative setting, such as the veto in Chadha, would still be invalid. 
sponded to the problem of what I shall call the "entrenching" presidential veto. Here is the story I will tell and the solution I will propose: The presidential veto in 1787 was meant to be purely reactive, to stifle bad laws and to prevent congressional encroachment on the executive. The presidential veto in the late twentieth century has become, at times, not a tool of reaction to congressional power but rather a method of shoring up or entrenching presidential power. ${ }^{209}$ If we insist on a two-thirds vote in each House to override an entrenching veto, we will have acquiesced not in the preservation of the veto as it was intended to work, but in its perversion. If, however, we recognize in some instances a simple majority of both Houses as sufficient evidence of congressional intent to stop a presidential lawmaking initiative, then we shall have prevented the President from using his veto to maintain a tight hold on concentrated legislative and executive powers. ${ }^{210}$ Just as independent agencies are a modern method of preserving an old value, so will recognizing the authority of a concurrent resolution, in certain narrowly defined situations, preserve rather than pervert constitutional meaning.

\section{A. The Presidential Veto in $\mathbf{1 7 8 7}$}

To the framers, the need for a presidential veto was clear. Again, the problem was how to establish a strong enough executive to combat a strong legislature. ${ }^{211}$ As Madison put it in Federalist 51 , "As the weight of the legislative authority requires that it should be thus divided, the weakness of the executive may require, on the other hand, that it should be fortified."212 In the debates, Madison had pushed for making the veto a joint presidential-judi-

${ }^{209}$ See Charles L. Black, Jr., Some Thoughts on the Veto, 40 L \& Contemp Probs 87 (Spring 1976). Black writes that "[t]he result of this asymmetry is that the President, with what might be thought meager textual powers, is institutionally almost untrammeled, since he may veto disapproving action by the very body to which he is supposedly subject, while that body, textually empowered to an enormous degree, is institutionally bound toe and neck by the veto." Id at 98 . See also Bruff, 88 Yale $L J$ at 469 (cited in note 9) ("It would shift too much power to the President if, with few limitations, he could issue orders to agencies that Congress could countermand only with the majorities necessary both to pass legislation and to override a subsequent presidential veto.").

210 Although the phrase "congressional intent" is often used as a synonym for "statutory purpose" once a statute has been enacted (either with the President's signature or over his veto), here I use it to mean the desire of a majority of Congress as an institution separate from the President.

${ }^{211}$ See, for example, Black, $40 \mathrm{~L} \&$ Contemp Probs at 89; Eskridge and Ferejohn, 80 Georgetown $\mathrm{L} J$ at 534 (cited in note 8).

${ }^{212}$ Federalist 51 (Madison), Federalist Papers at 322-23 (cited in note 23). See also Farrand, I Records at 98 (cited in note 56) (Wilson). 
cial act. Madison (and Wilson, the other key proponent of this measure) feared that the legislature would be too strong and the executive too weak, and thought that adding the judiciary would bolster the executive in exercising the veto. ${ }^{213}$ As Madison explained:

In short, whether the object of the revisionary power was to restrain the legislature from encroaching on the other co-ordinate departments, or on the rights of the people at large; or from passing laws unwise in their principle, or incorrect in their form, the utility of annexing the wisdom and weight of the judiciary to the executive seem[s] uncontestable. ${ }^{214}$

Although the proposal to join the judiciary to the veto was defeated, ${ }^{215}$ even those opposed to such a joinder agreed "that a check on the legislature is necessary,"216 and giving the President a qualified veto to check an overreaching legislature was never controversial.

In particular, the framers saw the veto as another way of ensuring against the concentration of legislative and executive powers. As Hamilton explained in Federalist 73, the veto was needed to defend the President against congressional "depredations"; otherwise, "the legislative and the executive powers might speedily come to be blended in the same hands."217 During the Convention, Mason argued that the veto was intended to ensure that the presidency should be "well secured against legislative usurpations on it. The purse and the sword ought never to get into the same hands whether legislative or executive."218

In short, it is clear that the presidential veto was meant to help a weak President combat a strong legislature, to prevent both encroachment on executive power and bad laws, and to ensure

${ }^{213}$ Farrand, I Records at 138 (Wilson); id (Madison); Farrand, II Records at 74 (cited in note 59) (Madison); id at 76 (Morris).

214 Farrand, I Records at 139 (cited in note 56) (Madison). See also Farrand, II Records at 73 (Wilson) (purpose of the veto is to stop laws that are "unjust," "unwise," "dangerous," or "destructive"). Hamilton explained the purpose of the veto in this way: "The primary inducement to conferring the power in question upon the executive is to enable him to defend himself; the secondary one is to increase the chances in favor of the community against the passing of bad laws, through haste, inadvertence, or design." Federalist 73 (Hamilton), Federalist Papers at 443 (cited in note 23).

${ }^{213}$ The proposal was raised and defeated four times. Farrand, I Records at 97-104 (defeated 8-2); id at 138-40 (defeated 8-3); Farrand, II Records at 73-80 (defeated 4-3, with 2 States divided); id at 298 (defeated 8-3).

${ }^{216}$ Farrand, II Records at 79 (Ghorum).

217 Federalist 73 at 442.

218 Farrand, I Records at 139-40. 
against the agglomeration of legislative and executive power in the same branch. For the President to use the veto to ensure that he maintains both legislative and executive power would have been unthinkable to the framers-unthinkable because unforeseeable, but also unthinkable because contrary to basic tenets.

\section{B. The Problem: The Entrenching Presidential Veto}

In Rust $v$ Sullivan, ${ }^{219}$ the Supreme Court upheld a regulation forbidding abortion counseling by doctors and nurses at clinics receiving federal funding. As a predicate to its constitutional holding, the Court interpreted the relevant statute, which stated, regarding federal Title X family planning funds, "[n]one of the funds appropriated under this title shall be used in programs where abortion is a method of family planning." ${ }^{220}$ Rejecting a seventeen-year-old practice of interpreting this provision as covering only abortions themselves, ${ }^{221}$ the Reagan Administration had issued a new interpretation, reading the provision to cover abortion counseling as well. ${ }^{222}$ Despite a significant statutory argument that Congress never intended to ban abortion counseling, the Rust Court deferred to the Administration and upheld the regulatory interpretation as not violating the statute. Rather, it determined that "the plain language and legislative history are ambiguous as to Congress's intent in enacting Title X," and thus deferred "to the Secretary's permissible construction of the statute." ${ }^{223}$ Later in 1991, and again in 1992, a substantial majority in both Houses of Congress voted to amend the statute to ensure that abortion counseling could continue in federally funded family planning clinics. ${ }^{24}$ But President Bush vetoed the bill both times, ${ }^{225}$ and the House

$219111 \mathrm{~S}$ Ct 1759 (1991). The regulation also prohibited abortion referrals, but I shall refer only to the counseling restriction.

${ }^{220}$ Public Health Service Act, Title X, Pub L No 91-572, 84 Stat 1508 (Dec 24, 1970), codified at 42 USC $\$ 300 a-6$ (1991).

${ }^{221}$ The original regulations provided that "[ $\left.t\right]$ he project will not provide abortions as a method of family planning." 36 Fed Reg 18466 (Sep 15, 1971), codified at 42 CFR $\S 59.5(a)(9)(1972)$.

${ }_{222}^{22} 53$ Fed Reg 2922, 2945 (Feb 2, 1988), codified at 42 CFR § 59.8(a)(1) (1989).

${ }^{223}$ Rust, $111 \mathrm{~S}$ Ct at 1769.

224 See 137 Cong Rec H9445 (Nov 6, 1991); 137 Cong Rec S16125 (Nov 7, 1991); 138 Cong Rec H7697 (Aug 6, 1992); 138 Cong Rec S13361 (Sep 14, 1992).

${ }^{225}$ See Weekly Compilation of Presidential Documents for Nov 19, 1991 and Sep 25, 1992. 
fell first 12 and then 22 votes short of an override. ${ }^{226}$ Thus was the President's novel rule encrusted into law.

No one of these steps seems in itself particularly unusual. A law was passed with sufficient vagueness for the Administration to tinker with its interpretation over time. Because the Court had insufficient evidence of congressional intent to forbid the revised interpretation, it deferred to the Administration's specification of an otherwise nonspecific statutory provision, and thus allowed the Administration to be, in essence, the lawmaker. Bills to change the law so as to overrule this executive interpretation were enrolled and sent to the President, but he vetoed them, and override attempts failed.

Furthermore, a set of doctrinal rules seems fully to justify this result. (A) Although Congress supposedly may not explicitly delegate lawmaking power, the nondelegation doctrine has been underenforced for the past fifty years, as I have explained above. Thus, it is well accepted that the Court may allow the executive branch to resolve statutory ambiguities, flesh out statutory vagueness, and fill in statutory gaps-all of which are interpretive lawmaking functions. (B) Although on one prominent view an Article III court must engage in careful, de novo review of an executive branch interpretation of a federal law to ensure fidelity to congressional purpose, after Cheuron, many lower courts and now, it appears, the Supreme Court (at least sometimes) will defer to an agency's reading of law if it seems plausible, even if the court might have determined a different reading to be "better" had it engaged in de novo review. ${ }^{227}$ (C) Although for many years Congress used a legislative veto to alter executive branch decisions, in INS $v$ Chadha, ${ }^{228}$ also discussed above, the Court invalidated the legislative veto on the ground that all congressional legislation must be presented to the President for his approval or disapproval, pursuant to Article I, Section 7. Thus, it would be constitutionally impermissible to recognize as law the congressional effort to abolish the abortion counseling "gag rule," for without the votes to override the President's veto, the congressional vote has a status no higher than a concurrent resolution, which, under Chadha, cannot be law.

${ }_{226}$ See 137 Cong Rec H10508 (Nov 19, 1991); 138 Cong Rec H10678 (Oct 2, 1992). The Senate never voted on the override in 1991; it voted 73-26 to override in 1992. See 138 Cong Rec S15957 (Oct 1, 1992).

227467 US 837,843 (1984).

${ }^{228} 462$ US 919 (1983). 
But even though no one step in the story of the abortion counseling gag rule was itself unusual, and even though each seems justified by a separate area of checks and balances doctrine, the end of this story seems very odd: A rather striking rule of law-one inhibiting speech by doctors to patients about an aspect of their medical condition-was made legally authoritative by the President rather than by Congress, and although a substantial majority of Congress preferred that such a rule not exist, the rule continued to govern. ${ }^{229}$ Thus has the executive branch gained extraordinary lawmaking power. ${ }^{230}$

\section{The Solutions: Revise Chevron and Revise Chadha}

The sort of unchecked presidential lawmaking exemplified by the Rust story is not inevitable. Congress could, of course, delegate more specifically, and the Court could invalidate broad delegations. But as I have suggested above, perhaps we should accept the legitimacy of broad, judicially sanctioned delegations of lawmaking power to the President-that is, we should accept the post-New Deal world as one starting from a premise of presidential lawmaking. Simply because we start from a new premise does not mean, however, that we must accept the resulting allocation of power. To be true to the framers' core concern of ensuring against concentrated power in either Congress or the President, power that we have good reason to be concerned about today, it is proper to ask whether our contemporary doctrinal tools are suitable. As I have explained above, the creation (and validation) of independent agencies is one way to ensure against presidential tyranny. When Congress has not seen fit to create independent agencies, however, the combination of broad deference to presidential regulations and refusal to give legal weight to a congressional concurrent resolution might result in the very vice the framers meant to combat.

${ }^{229}$ Shortly after taking office, President Clinton set in motion the process to rescind the gag rule. See 58 Fed Reg 7455 (Jan 22, 1993) (memorandum ordering Secretary of Health and Human Services to suspend the gag rule and issue a notice of proposed rulemaking for its rescission); Department of Health and Human Services, Standards of Compliance for Abortion-Related Services in Family Planning Service Projects, 58 Fed Reg 7462 (suspension of the gag rule); $58 \mathrm{Fed}$ Reg 7464 (notice of proposed rulemaking for the gag rule's rescission).

${ }^{230}$ Although it is hard to find precise analogues to the history of the Rust legislation, in which Congress actually reached the point of a failed veto override, presidential lawmaking is often unguided by antecedent congressional intent, and therefore Congress is often in the position of being able to reject such lawmaking only by overriding a likely presidential veto. 
There are two ways (not mutually exclusive) to address this problem. The first is to modify Cheuron (as currently interpreted) and reject broad deference to presidential lawmaking masked as "regulatory interpretation." The second is to modify Chadha in those circumstances in which a congressional concurrent resolution would function not as congressional aggrandizement, but rather as a check on presidential tyranny. ${ }^{231}$

\section{Revising Cheuron.}

The problem of exorbitant deference to presidential regulatory interpretations was not caused by Cheuron itself. That case, decided by a unanimous Court, seemed to state a fairly obvious principle: If congressional intent is clear, the agency must follow it (this is Cheuron stage one); if congressional intent is unclear, the agency may choose any rational statutory application (this is Chevron stage two). ${ }^{232}$ The key question was how searching the judicial examination of congressional intent should be. In Chevron, the Court looked quite closely at statutory text and legislative history before concluding that Congress had indeed been silent on the relevant question. ${ }^{233}$ Using Chevron itself as an example of how a reviewing court should view its interpretive relationship with the agency, one would likely conclude that the court should defer to the agency's interpretation only if the court could not find evidence to the contrary. But in a footnote, the Chevron Court suggested that a reviewing court should defer to an agency interpretation if it is reasonable, even if the court would have reached a different interpretation on de novo review. ${ }^{234}$ It is this statement-perhaps best seen as dicta in light of the Court's searching, hands-on analysis of congressional intent-that has led to rather broad Cheuron deference. Instead of engaging in a hands-on historical examination of congressional intent, many courts now defer to what seems a reasonable agency interpretation, avoiding the question: "Is the agency's interpretation the best reading of congressional intent?"235 Rust represents a classic example of this broad deference at the Supreme Court level.

231 See Black, 40 L \& Contemp Probs at 98-99 (cited in note 209). For an argument for a much broader use of the two-house veto to reassert congressional prerogative, see Eskridge and Ferejohn, 80 Georgetown L $\mathrm{J}$ at 543 (cited in note 8).

232467 US at 842-43.

$23 s$ Id at 845-66.

234 See id at $843 \mathrm{n} 11$.

${ }^{235}$ See INS v Cardoza-Fonseca, 480 US 421, 452-55 (1987) (Scalia concurring in the judgment); Cynthia R. Farina, Statutory Interpretation and the Balance of Power in the 
Since the disease I am discussing is unchecked presidential lawmaking, the cure must involve some sort of check from either Congress or the courts. One possible cure would be to insist on an historical, searching, de novo judicial effort to ascertain congressional intent and force the President to abide by it. Even this, though, leaves many cases-indeed, the most problematic cases from a checks and balances standpoint-untouched. When sufficient evidence of congressional intent exists to restrict presidential choice, a beefed-up Cheuron would enlist the judiciary as Congress's agent in tethering the President to that intent. This would be an advance, to be sure. But in many cases, even after searching judicial scrutiny, congressional intent remains ambiguous, vague, or nonexistent. In these cases, even a court committed to de novo review of regulatory interpretations would be compelled to defer to the President, and to recognize that the President has become the lawmaker. ${ }^{236}$ A beefed-up Cheuron helps solve some of the problems of unchecked presidential lawmaking, but it suffers from the main vice of the delegation of legislative power: Sometimes Congress simply had nothing in mind.

It is worth noting one additional point about the evolution of Chevron into a principle of broad deference. The nondelegation doctrine, as administered by the Court today, might be in tension with Cheuron, as understood by the Court today. The Court has frequently upheld a vague statute against a nondelegation doctrine challenge by saying something like, "Well, the statute isn't really all that vague, for here are sources of constraint that bind the agency and the court, such as administrative practice, cases, and legislative understandings." 237 This reasoning, while somewhat creative, is probably appropriate. In many Cheuron cases, however, courts reaching Cheuron stage two effectively say, "We can't find

Administrative State, 89 Colum L Rev 452, 454 (1989); Antonin Scalia, Judicial Deference to Administrative Interpretations of Law, 1989 Duke L J 511, 520; Cass R. Sunstein, Law and Administration After Chevron, 90 Colum L Rev 2071, 2074 (1990).

${ }^{236}$ See Greene, $1991 \mathrm{~S} \mathrm{Ct} \mathrm{Rev} \mathrm{at} \mathrm{274-82} \mathrm{(cited} \mathrm{in} \mathrm{note} \mathrm{4).} \mathrm{Alternatively,} \mathrm{we} \mathrm{could} \mathrm{revise}$ Cheuron so that it would authorize a reviewing court at Cheuron stage two to choose what it deemed the best policy from those available under the terms of a vague statutory provision. This would ensure against concentration of power in the President, but at the cost of ceding power to Article III judges, who are even less accountable than independent agencies and who have no particular expertise in policy making. A modified version of this "remedy" in Chevron stage two cases is to defer outright to the President when Congress has expressly granted him policy-making power under the relevant Act, but to take executive agency regulations as merely persuasive authority if they are filling gaps left inadvertently by Congress. Compare Skidmore v Swift \& Co., 323 US 134, 140 (1944).

${ }^{237} \mathrm{See}$, for example, cases cited in note 40 . 
any constraints in the relevant legal materials, and therefore the President gets to choose the policy (interpretation)." A judge adopting this position of substantial deference would not be constrained by the extra-textual factors in the nondelegation doctrine cases. Conversely, a judge fending off nondelegation doctrine challenges by looking harder for external constraints on vague statutory delegations would limit the scope of Cheuron deference. Given the need to limit presidential lawmaking, the latter is the better accommodation.

\section{Revising Chadha.}

Instead of always requiring a two-thirds majority of both houses, permitting a concurrent congressional resolution to block presidential lawmaking in certain instances would fill the gap left when the prior delegating Congress had nothing in mind and a subsequent Congress can assemble enough votes to take a firm stand. Perhaps we should recognize such concurrent resolutions as authoritative if they are styled expressly as amendatory clarifications responsive to otherwise unguided presidential lawmaking. This would certainly stem the tide of presidential power, in a setting in which it seems accurate to describe the congressional resolution not as an extra-constitutional grab for power, but only as a check on the President.

The problem with this reasoning is that Chadha seems to reject it. ${ }^{238}$ Chief Justice Burger's majority opinion is no model of clarity, but the Court clearly rebuffed Justice White's dissenting claim that the legislative veto serves to rebalance powers between the branches. Chadha itself resulted from a one-house veto of an adjudicatory decision, rather than a concurrent resolution veto of a regulation. But the Court's message from both Chadha and postChadha per curiam decisions in the regulation setting is that congressional action without presentment to the President should be invalidated as a congressional grab for power. ${ }^{238}$

But this refusal to allow Congress to control presidential lawmaking through anything but a properly enacted law is inconsistent with Youngstown Sheet \& Tube Co. $v$ Sawyer, ${ }^{240}$ which introduced an important method of controlling presidential power through examining congressional action short of enacted laws. In

238 Compare Gewirtz, $40 \mathrm{~L}$ \& Contemp Probs at 78-79 n 129 (cited in note 34), anticipating Chadha.

${ }^{238}$ See cases cited in note 157.

${ }^{240} 343$ US 579 (1952). 
Youngstown, President Truman had ordered federal seizure of privately owned steel mills during a strike, on the theory that his power as Commander-in-Chief authorized him to deem the action necessary to supply the troops in Korea. ${ }^{\mathbf{2 1 1}}$ After rejecting this claim, the Court asked whether Congress had either delegated or forbidden seizure power to the President. Justices Black and Vinson seemed to require express congressional action-Black, as a prerequisite for presidential power; ${ }^{242}$ Vinson, as a prerequisite for a prohibition on such power. ${ }^{243}$ But the controlling opinions, authored by Justices Jackson and Frankfurter, ${ }^{244}$ looked not just to Acts of Congress that expressly authorized or prohibited seizures, but also to other evidence of congressional intent in the general area of seizures during labor disputes. ${ }^{245}$ Congress had delegated certain powers to the President to deal with labor strikes dangerous to national security and had refused to adopt an amendment to the Taft-Hartley Act that would have delegated seizure power. Although Congress had not expressly forbidden seizure power, Jackson construed the landscape of legislation as evidence of congressional intent to deny seizure power to the President. Furthermore, although Jackson's discussion of how the Court should proceed in the face of pure congressional silence (neither express laws nor inferences) is perhaps deliberately obscure, there is a strong inference that Jackson would have permitted presidential action in such a "zone of twilight" case. ${ }^{246}$ Thus, evidence of congressional intent to constrain presidential action was necessary to Jackson's conclusion that the President had acted unconstitutionally, even though that evidence did not include an Article I, Section 7 denial of seizure power.

In this way, Youngstown recognized what Chadha failed to recognize: Congress's "voice" matters regarding the nature and scope of presidential power, and to hear that voice one must sometimes go beyond enacted authorizations or prohibitions. Reliance on implications from the legislative landscape was seen in Youngstown not as judicial deference to congressional aggrandizement, but rather as judicial implementation of congressional control on presidential action, albeit through a somewhat unusual channel. In

241 Id at $582-83$.

242 Id at 585.

${ }^{243}$ Id at 701-04 (Vinson dissenting).

${ }^{244}$ See Dames \& Moore v Regan, 453 US 654, 668-69 (1981) (focusing on Jackson's opinion in Youngstown).

${ }^{245}$ See Gewirtz, $40 \mathrm{~L} \&$ Contemp Probs at $81-82$ (cited in note 34).

${ }^{246}$ Youngstown, 343 US at 637-38. 
fact, one can see Jackson's Youngstown methodology as a balancing response to the demise of the nondelegation doctrine: even though courts will not invalidate delegations as too broad, they still can construe the landscape of legislation to forbid delegation, if delegation seems in tension with Congress's wishes. In this way, presidential power is kept in check.

There is, though, a potential problem with extending this argument to the Rust-type case. Youngstown deals with action initiated by the President: Truman had issued an executive order to seize the mills, supported by (so the Court said) neither Article II power nor a specific, express delegation of power from Congress. To allow Truman's action to go forward unless Congress overrode it through the Article I, Section 7 process (as Chief Justice Vinson advocated) would make checking the President extraordinarily difficult, for presumably Congress would need a two-thirds vote in each House to override an assured presidential veto. The resulting power sequence has the President as the initiator of federal action, Congress next in a reactive position, the President next, with his veto, and Congress last, in the override position. This presents a tough situation for Congress. ${ }^{247}$ Because Congress is acting purely reactively in a Youngstown-type case, one could argue that requiring a supermajority in both Houses to check the President throws the balance of powers out of whack, threatening to leave the President with an extraordinary combination of policy making and executive powers.

Arguably, the Rust-type case has a different power sequence. ${ }^{248}$ There, one might contend, Congress moves first, delegating power, albeit broadly and vaguely. Next follows presidential implementation of that delegated power. In this setting, if Congress wants to challenge the President's regulatory interpretation, it might make sense to require more than a concurrent resolution, to require, instead, presentment and override, if need be. For here, unlike in the Youngstown-type case, Congress is reacting not to a pure exercise of presidential power, but to a derivative one, to the President's acting as Congress's agent in the first instance, through its delegation. As wise as Jackson's arguments from implication

${ }^{247}$ See Paul G. Kauper, The Steel Seizure Case: Congress, the President and the Supreme Court, 51 Mich L Rev 141, 181 (1952); Harold Hongju Koh, Why the President (Almost) Always Wins in Foreign Affairs: Lessons of the Iran-Contra Affair, 97 Yale L J 1255, 1303-04 (1988).

${ }^{248}$ Compare Bruff, 88 Yale L J at 473-74 (cited in note 9), arguing that Jackson's Youngstown analysis works better in some situations than others. 
might seem when the President is truly the first mover, perhaps such arguments are inapposite when Congress is responding to a President acting through congressional delegation.

But this response threatens a return to the old premise. One of the principal points of this Article has been to establish a new premise, to suggest that we must start looking at the allocation of power between the President and Congress from the baseline that the President possesses a large amount of lawmaking power unchecked by antecedent congressional intent. If we start with such an assumption-while remaining properly constitutionalist and thus bearing in mind the framers' overarching principle of balance of powers, and of ensuring against the control of both legislative and executive power by either Congress or the President-then we should see the Rust-type case and the Youngstown-type case as comparable, not distinguishable. From the post-nondelegation doctrine premise, President Reagan's policy choice to impose the abortion counseling gag rule was unchecked ex ante just as President Truman's seizure order was; Reagan's policy choice was as much a presidential first move as Truman's. A concurrent resolution denying Truman's seizure power would certainly have been sufficient for Jackson to conclude that Congress had spoken and must be obeyed. The same should hold true for Congress's concurrent resolution opposing the abortion counseling gag rule. In this regard, it is interesting to note that President Truman evidently was willing to abide by Congress's will after his steel seizure order; that is, he would have withheld his veto and accepted as binding (what would have amounted to) a concurrent resolution. ${ }^{249}$ This indicates-though probably only implicitly_Truman's acceptance of a mere majority vote in both houses as trumping independent presidential policy making in the domestic arena.

Let me suggest that both the Youngstown-type case and the Rust-type case should be seen as constituting a special category of presidential power. In this category, a presidential veto is used to entrench presidential policy, and a concurrent resolution should therefore be acknowledged as a check on that entrenchment. Consider first the following categories of presidential power:

${ }^{248}$ See Youngstown, 343 US at 701 (Vinson dissenting) ("Nor is there any question of unlimited executive power in this case. The President himself closed the door to any such claim when he sent his Message to Congress stating his purpose to abide by any action of Congress, whether approving or disapproving his seizure action."). 
(1) Nonregulable presidential power. In this category, covering powers granted to the President's sole discretion by Article II of the Constitution, Congress may not regulate presidential action. For example, Congress could not seek to dictate a battlefield command. ${ }^{250}$ Also, Congress could not require the President to nominate a particular person to the Supreme Court, or forbid the President from pardoning a particular person. ${ }^{251}$

(2) Presidential power that is regulable only through an Act of Congress. In this category, the President would be disabled from acting if Congress had already passed a law conclusively barring his intervention. Further, if there were no express law barring his action and the President acted, Congress could stop the action through a subsequent law. Foreign affairs power, I believe, fits into this category. Consider, for example, Dames \& Moore $v$ Regan. ${ }^{252}$ The issue was whether President Reagan had properly ordered the suspension of domestic claims against the government of Iran. The Court stated that Justice Jackson's three-part framework from Youngstown was "analytically useful," but that "executive action in any particular case falls, not neatly in one of three pigeonholes, but rather at some point along a spectrum running from explicit congressional authorization to explicit congressional prohibition."253

The Court concluded that although no statute expressly authorized the suspension of claims, the "general tenor" of related statutes indicated congressional authorization in this area. ${ }^{254}$ As critics have noted, the results in Youngstown and Dames \& Moore cannot easily be squared. ${ }^{255}$ In neither case had Congress expressly authorized or blocked the presidential action, but in Youngstown, the Court read the "mood" of the statutory landscape as anti-authorization, while in Dames \& Moore, the Court read the "mood" of the statutory landscape as pro-authorization.

In my view, Dames \& Moore is best read as implicitly applying Chief Justice Vinson's dissenting approach from Youngstown. There, Vinson had argued that the President should be permitted

${ }^{2 s 0}$ US Const, Art II, $\S 2, \mathrm{cl} 1$ (Commander-in-Chief Power).

${ }^{251}$ US Const, Art II, \& 2, cl 2 (Nomination Power); US Const, Art II, § 2, cl 1 (Pardon Power).

252453 US 654 (1981).

253 Id at 669.

254 Id at 678 .

${ }^{235}$ See, for example, Geoffrey R. Stone, Louis M. Seidman, Cass R. Sunstein, and Mark V. Tushnet, Constitutional Law 387 (Little, Brown, 2d ed 1991). 
to act, subject to congressional denial of power by law. Reading Dames \& Moore as subjecting the President's actions to this test makes sense in the foreign affairs setting, where the division of power between Congress and the President has always been murky and where the President has long taken the initiative, with considerable congressional acquiescence. Thus, we should understand this second category as permitting the President to act, subject to either an ex ante or ex post act of Congress forbidding such action. $^{256}$

(3) Intermediate category of presidential power. I will argue that there is an intermediate category of presidential power that is regulable through congressional action short of an Article I, Section 7 law; let me return to it in a moment.

(4) Presidential power that is available only through an extant Act of Congress. There are some powers that the President may wield, but only after Congress has delegated them through law. Examples are plentiful: The President may not establish the Medicaid program, or any programmatic federal initative, without congressional authorization. Justice Black in Youngstown deemed most domestic presidential action to fall within this category, but as noted above, the controlling opinions of Justices Jackson and Frankfurter clearly left room for legitimate domestic presidential action even without clear authorization from either Congress or Article II. ${ }^{257}$ It is likely that the Court would not strike down a presidential response to what appeared to the Court to be a real domestic emergency. ${ }^{258}$

(5) Presidential power that isn't available at all. There are two types of situations in which the President has no power, no

${ }^{258}$ See Eskridge and Ferejohn, 80 Georgetown L J at 554-56 (cited in note 8) (criticizing Dames \& Moore as relying on congressional silence in approving presidential action); id at 562 (would "reinterpret Dames \& Moore . . . as a decision that the President has at least some inherent powers to settle claims under Article II of the Constitution"). See also Koh, 97 Yale L $\mathrm{J}$ at 1311 (cited in note 247).

${ }^{287} 343$ US at 585 (Black), 610 (Frankfurter), 637 (Jackson).

${ }^{268}$ The Court might not expressly validate such power, either. Rather, it might either dismiss the matter as a political question, or interpret some congressional legislation as implicitly authorizing the action. In either way, it could allow the President's action to go forward without the imprimatur of a general judicial validation of presidential emergency power. See Alexander M. Bickel, The Least Dangerous Branch: The Supreme Court at the Bar of Politics 127-33 (Yale, 1962) (discussing the drawbacks of the Court's legitimizing actions by the political branches). This is another way of understanding Dames \& Moore. 
matter what Congress does. One involves invasions of individual constitutional rights; the other involves certain types of power that Congress may not be free to delegate. For example, strong arguments could be made that Congress may not delegate to the President the power to declare war, or to propose amendments to the Constitution.

Now let me return to my proposed category (3): Presidential power that is regulable through congressional action short of an Article I, Section 7 law. Chadha, of course, seems to preclude this, but as I have shown above, Justice Jackson's reliance on inferences from congressional action short of law in Youngstown might enhance the analysis. I have attempted above to establish an analogy between the Youngstown-type case and the Rust-type case where the President acts as a lawmaker, unconstrained by antecedent congressional intent. ${ }^{259}$ Even if one accepts this analogy, one might respond that Jackson's approach was wrong and should not be repeated. I must confess to sharing some apprehension about relying upon a defeated amendment from the consideration of the TaftHartley Act to conclude that Congress "intended" to deprive the President of the seizure power in question. But perhaps we can narrow this third category; I shall address the Rust-type case, because it is that type of case with which I am chiefly concerned. The analysis applies, though, by analogy to the Youngstown-type case as well.

Here are my five proposed narrowing conditions for recognizing congressional action short of a law as sufficient for controlling presidential action. First, only concurrent resolutions should suffice. I would count as a concurrent resolution any bill that gains majority support in both Houses, whether the bill is styled as a Concurrent Resolution and not submitted to the President, or styled as an Act or Joint Resolution and is submitted to the President. Evidence of congressional intent short of the votes needed to support a concurrent resolution would, however, be insufficient. Hence, Congress could reject presidential action in a Rust-type case only if it had enough votes to enroll a bill and send it to the President--that is, if it had a number of votes that would have

250 There are other possible examples, of course, of category (3) cases. There is fairly strong support in the literature for the constitutionality of section 5(c) of the War Powers Resolution, which requires that the President remove troops from hostilities pursuant to a concurrent resolution. See Carter, $70 \mathrm{Va}$ L Rev at 130-32 (cited in note 131); Casper, $43 \mathrm{U}$ Chi L Rev at 484-85 (cited in note 6); John Hart Ely, Suppose Congress Wanted a War Powers Resolution that Worked, 88 Colum L Rev 1379, 1395 (1988); Note, The Future of the War Powers Resolution, 36 Stan L Rev 1407, 1432-33 (1984). 
been sufficient to enact legislation had there been a sympathetic President.

Second, the concurrent resolution should be authoritative only to the extent that it blocks the President's regulation; Congress could not use the resolution as an excuse to make other legislative moves. In this way, such resolutions would serve as a sort of congressional remand to the President: Congress would not say what the President must do, but would simply say what he may not do. ${ }^{260}$

Third, the President would have to be exercising authority pursuant to an implicit rather than explicit delegation from the initial law. If Congress expressly enacted a provision saying, "With regard to particular issue $X$, the President shall decide"-or (what is more likely) "the Secretary of Department $Y$ shall have rulemaking and adjudicative authority to make rules with regard to particular issue X"-then Congress would need votes sufficient to override a presidential veto if it wished to alter the President's regulation. Of course, it makes no sense to expect Congress to anticipate every future twist and turn of a law's application. But if Congress has expressly delegated resolution of a particular issue to the President, then that express delegation is a clear term of the law that must be altered through the normal Article I, Section 7 process, just as a repeal of the law would require such process. Many regulatory actions arise not from express delegations, however, but rather from "implicit delegations"-although this term is admittedly an oxymoron, expressing not a choice that Congress has made, but rather a normative systemic decision to permit regulatory actions to fill vagueness, ambiguities, and gaps. In those situations, my rule should hold.

Does this give Congress an incentive to delegate vaguely and take charge at the back end? I think not; or at least it should be clear that such strategic behavior will not often occur. To do this, Congress would have to know that, at some undefined future date, it will have majorities in both Houses to stop a particular presidential regulation, while simultaneously knowing that it will not have supermajorities to enact its desired outcome over a veto. Furthermore, Congress would have to assume that the President would sign the initial legislation, which he might not do if he knew what Congress were up to-and it might be hard for Congress to conceal this from him at such a massive level of conspiracy.

${ }^{280}$ See SEC v Chenery Corp., 318 US 80 (1943) (establishing a similar rule for judicial remand to administrative agencies). 
Fourth, even in a case of implicit delegation, if a presidential regulatory interpretation is required under Cheuron stage one, then a concurrent resolution would not be sufficient to alter the prior law. In such a case, the President would be following antecedent congressional intent, rather than making policy on his own. Only in a Cheuron stage two case, where it is correct to say that the President has made policy on his own, should it be appropriate for a concurrent resolution to reject such a policy. In this way, the Cheuron two-stage analysis can help us understand the pure lawmaking Presidents engage in, and help us adjust other areas of doctrine accordingly. ${ }^{261}$

Finally, this analysis applies to executive agencies, but not to independent agencies. The problem is the concentration of lawmaking and executing power in the President; as I have explained above, although independent agencies often combine legislative and executive functions, we can nonetheless single out presidential aggrandizement as a unique problem worthy of special attention.

To sum up my proposal: If the President (or any executive agency) promulgates a regulation pursuant to a law that neither expressly authorizes presidential resolution of the particular issue nor clearly resolves the issue as a matter of antecedent congressional intent, a subsequent concurrent resolution should be construed as sufficient to block the regulation. ${ }^{262}$ I recognize that in cases such as this, neither the President nor Congress would have the votes to enact its desired policy. Congress would refuse to enact the President's policy, the President would veto Congress's policy, and Congress could not override the veto. Either possible solution to this gridlock is, to some degree, imperfect, because it must either allow the President to make law without Congress's consent, or allow Congress to make law without the President's consent. Yet if we accept the former, we accept the concentration of lawmaking and executing powers in the President, while if we accept the latter, we remain true to the core principle of dividing such powers. ${ }^{263}$

${ }^{261}$ See Greene, $1991 \mathrm{~S}$ Ct Rev 261 (cited in note 4) (We should revise our approach to administrative adjudicative retroactivity to reflect the pure policy making agency adjudicators sometimes do.).

${ }^{282}$ If my proposal were accepted as a proper construction of the balance of powers in the post-nondelegation doctrine era, then Presidents could avoid litigation by acknowledging the force of a concurrent resolution in these cases, just as Truman was apparently willing to do in Youngstown. See text accompanying note 249.

${ }^{283}$ I recognize that we might also be facing the converse problem of the entrenching presidential veto: omnibus bills that render the veto power nugatory in many instances. One might develop a structural argument that "bill" in Article I, Section 7 was understood as having a germaneness requirement. If so, omnibus bills are perhaps either unconstitutional, 


\section{CONCLUSION}

We cannot properly examine the constitutional balance of power between the President and Congress if we assume that Congress legislates and the President executes. Rather, we should begin from a new premise, that of presidential lawmaking. For since the New Deal, Congress has delegated much lawmaking power to the President, without judicial invalidation. The framers of the Constitution were centrally concerned with avoiding the concentration of executive and legislative powers in the same hands. This concern should be ours as well, both because of the harm that concentrated power can bring and the good that can result from diffused power. Much, but not all, of post-New Deal checks and balances jurisprudence can be justified from these premises-that the delegation of legislative power is permissible, but that the concentration of power in one branch is still troublesome. Thus, the Court has properly upheld laws that fracture the executive by establishing independent agencies, which help to diffuse the power that would otherwise be concentrated in the President. At the same time, the Court has properly invalidated laws that, while seeking the end of balance between the branches, operate through the means of concentrating power back in Congress.

Despite the general reasonableness of these decisions, a loophole remains: the "entrenching" presidential veto. The use of the veto to entrench presidential lawmaking rather than to prevent congressional overreaching is an inversion of the veto's original purpose-an inversion serving to enhance the agglomerated legislative and executive power that the President now holds. In certain limited situations, we should accept a majority vote in both Houses of Congress as sufficient to block presidential lawmaking, thereby preventing the presidential veto from forcing an override. This mechanism might be far from the specific structure that the framers envisioned, but it is far closer to their underlying principles than the present system, which allows the President to make policy while effectively preventing Congress from doing anything about it.

or permissible but subject to a line-item veto. Compare William A. Clineburg, The Presidential Veto Power, 18 SC L Rev 732, 750-54 (1966); Stephen Glazier, The Line-Item Veto: Provided in the Constitution and Traditionally Applied, in Pork Barrels and Principles: The Politics of the Presidential Veto 9, 11 (National Legal Center for the Public Interest, 1988). But see Michael B. Rappaport, The President's Veto and the Constitution, $87 \mathrm{Nw} \mathrm{U}$ L Rev 735 (1993) (The Constitution does not restrict the definition of "Bill" in Article I, Section 7.). 